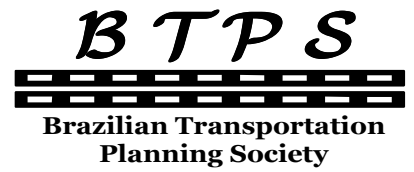
Journal of Transport Literature
Vol. 8, n. 2, pp. 134-177, Apr. 2014
Research Directory

JTL|RELIT

www.transport-literature.org ISSN 2238-1031

\title{
A spinoffs study applied to the airline industry
}

[Um estudo de "spinoffs" aplicado à indústria do transporte aéreo]

\author{
Erika Kutscher* \\ Massachusetts Institute of Technology - United States
}

Submitted 14 Apr 2013; received in revised form 1 Jul 2013; accepted 7 Jul 2013

\begin{abstract}
Airlines have been recently debated the management of some of their non-core divisions, such as the Frequent Flyer Program (FFP). A spinoff is a form of corporate contraction that many companies have recently chosen. Through a spinoff, both the parent company and the divested subsidiary can each focus on their own activity, which translates into a better performance of both entities. This paper studies the circumstances in which a spinoff is a good strategy to pursue, along with some important issues that must be considered when reaching agreements. Spinoffs are basically a "downsizing" of the parent firm; therefore, the smaller firm must be economically more viable by itself than as a part of its parent company. The motivation for analyzing this particular topic comes from a question of current interest: Under what circumstances is it advantageous for an airline to spin off its Frequent Flyer Program, or other divisions that are not related with the airline's operation? In this paper, an extensive literature review introduces the reader to the different forms of corporate contraction and their performance under different circumstances. Three cases related to the airline industry follow: the spinoffs of TripAdvisor from the web agency Expedia, of Air Canada's FFP Aeroplan, and of American Airline's distribution system Sabre. These three cases illustrate some of the key issues that must be carefully considered when spinning off a subsidiary. The paper concludes that spinoffs are a smart strategy when the focus of the spun off division is different from that of the parent company. However, to safeguard future business relationships, the two entities must negotiate detailed agreements that are robust enough to perform successfully in all foreseeable circumstances.
\end{abstract}

Key words: airlines, spinoff, strategic management.

\section{Resumo}

As empresas do setor aéreo têm sido discutidas recentemente quanto à gestão de algumas das suas divisões não-essenciais, como seus Programas de Milhagem. Uma "spinoff" é uma forma de contração que muitas empresas recentemente escolhido. Através de um spinoff, tanto a controladora quanto a controlada podem se concentrar em sua própria atividade, o que se traduz em um melhor desempenho de ambas as entidades. Este trabalho estuda as circunstâncias em que um spinoff é uma boa estratégia de ser perseguida, juntamente com algumas questões importantes que devem ser considerados para se chegar a tais acordos. Spinoffs são, basicamente, um "downsizing" da empresa-mãe e, portanto, a empresa menor deve ser economicamente mais viável por si só, do que como uma parte de sua controladora. A motivação para analisar este tema específico vem de uma questão de interesse atual: Em que circunstâncias seria vantajoso para uma companhia aérea a se desfazer de sua divisão de Programa de Milhagens, ou de outras divisões que não estão diretamente relacionados com a operação da companhia aérea? Neste trabalho, é realizada uma revisão da literatura apresentando as diferentes formas de contração corporativa e seu desempenho em diferentes circunstâncias. Três casos relacionados com a indústria da aviação são abordados: os spinoffs do TripAdvisor da agência web Expedia, do Programa de Milhagem Aeroplan da Air Canada, e do sistema de distribuição Sabre da American Airlines. Esses três casos ilustram algumas das principais questões que devem ser cuidadosamente considerados quando do spinoff de uma subsidiária. 0 trabalho conclui que os spinoffs são uma estratégia inteligente quando o foco da divisão removida é diferente daquele da empresa-mãe. No entanto, para salvaguardar as relações de negócios futuros, as duas entidades devem negociar acordos detalhados que são robustos o suficiente para desempenhar com sucesso em todas as circunstâncias antecipáveis.

Palavras-Chave: companhias aéreas, spinoff, estratégia.

*Email: ekutsche@gmail.com.

\section{Recommended Citation}

Kutscher, E. (2014) A spinoffs study applied to the airline industry. Journal of Transport Literature, vol. 8, n. 2, pp. 134-177.

- JTL/RELIT is a fully electronic, peer-reviewed, open access, international journal focused on emerging transport markets and published by BPTS - Brazilian Transport Planning Society. Website www.transport-literature.org. ISSN 2238-1031. 


\section{Introduction}

Managing the airline industry poses many challenges - intense competition, large fixed costs and strong suppliers of goods and services complicate the situation. This hostile environment forces airlines to push the boundaries and come up with creative ideas to improve the business. Corporate restructuring is commonly used in this sector; Mergers and Acquisitions (M\&A) have been used extensively to generate synergies in costs and networks. M\&A are front-page events in newspapers worldwide, and a large number of academic studies cover this topic. Corporate contractions such as spinoffs occur far less frequently and receive much less attention despite the fact that they unlock significantly more value for the shareholders than M\&A do.

In the airline industry, spinning off a Frequent Flyer Program (FFP), for example, can be very controversial. FPPs improve the profitability of the industry in two very important ways: first, they generate a massive amount of information that boosts the capacity of the airline to forecast passenger demand; and second, they reduce, to some extent, the price competition among airlines by making the passenger less price sensitive. Unlike the airline industry, the FFP business has a more benign competitive environment with low fixed costs and captive customers.

At first glance, it appears that the FFP would be a textbook candidate for a corporate contraction; however, only one airline has spun off that division completely. Can an airline avoid conflict of interests between its main operations and the FFP business? Under what circumstances is it better to separate them to maximize shareholder value? What actions are needed to increase the chances of success in a separation? These are the type of questions that many airlines and investors are asking.

The main goal of the paper is to understand the key factors that are important in the success of corporate deconglomeration, focusing in particular on the airline industry. To find these key success factors, the paper describes the different types of corporate contractions from tracking stocks to sell-offs, covering also intermediate alternatives such as spinoffs and equity carveouts. This paper discusses the existing academic literature on the theoretical and empirical 
performance of different types of corporate deconglomeration to understand what type of performance would be expected in a generic case. Then, examples in the airline industry are presented and analyzed in detail. Finally, this work explores and identifies new sources of failure or success and presents conclusions and recommendations.

This paper is organized in the following way. Section 1 identifies the different types of corporate contractions providing an historic perspective of their use and performance, along with the theoretical sources of value and the literature concerns. Section 2 presents three different examples of spinoffs from the airline industry in detail: Expedia and TripAdvisor, Air Canada and Aeroplan, and American Airlines and Sabre. The last section presents conclusions by contrasting the examples with the academic literature and with each other.

\section{Corporate contractions in the finance literature}

The academic finance literature includes considerable discussion of corporate expansion in the forms of mergers and acquisitions (M\&As). Literature about corporate "downsizing" is less extensive, perhaps because breaking up can be perceived as a failure. Nevertheless, there are still many articles and papers that focus their attention on the different forms of divesting a firm and the results that this restructuring strategy yields. Many of these were written in the 1990s, a time in which spinoffs and other forms of corporate downsizing became very popular. This Section summarizes the knowledge and main findings of the available literature. It starts by defining the different forms of corporate contraction, continues by showing the historic trends and ends by analyzing the results. Studies that analyze the source of value on those results are then presented, closing with general concerns and costs that need to be taken into account when performing a corporate contraction.

\subsection{The different forms of corporate contraction}

This section describes the most popular types of corporate contraction or divestitures and summarizes them in four types: tracking stocks, spinoffs, equity carve-outs and sell-offs.

Tracking stocks, also known as letter or targeted stocks, are described by Anslinger et al. (1999) as a class of partner company stock that tracks the earnings of a division or subsidiary. 
Typically distributed as a dividend to shareholders in the parent company, these shares can also take the form of an initial public offering (IPO). The control of the subsidiary's operation remains in the hands of the parent company's board as in one big company. However, through this form of restructuring, investors can be aware of the profitability of parent and subsidiary separately, which can be valuable information if the two entities are in different industries. Tracking stocks can be useful as an acquisition currency.

In 1999, the Walt Disney Company issued tracking stocks for its web portal go.com right when the dot-com bubble was emerging. When go.com was able to be valuated separately, and in times when all the dot-coms were being highly valuated, Disney's shareholders value increased significantly. When the bubble ended, Disney decided to retire the tracking stock (Lankford, 2000).

Spinoffs have a wide range of definitions and no common definition has emerged yet. Some authors use the term spinoff for any type of corporate contraction, while others are more specific. This paper considers that spinoffs occur when an entire subsidiary of a parent firm becomes an independent business with separate shares, separate managers that run the company independently, and separate assets and liabilities. Similarly to tracking stocks, the ownership is divided among shareholders of the parent firm as a dividend, in a pro-rata basis. Because the new shares are just given and not sold, spinoffs (and tracking stocks) are tax-free transactions in the US.

Two particular forms of spinoffs are split-offs and split-ups. The difference with respect to a traditional spinoff, as explained by Tübke (2005), is that in a split-off shareholders of the parent firm receive shares in a subsidiary in return of relinquishing their parent company shares. Split-ups, on the other hand, occur when the parent company spins off all its subsidiaries to its shareholders and ceases to exist. The parent shares are exchanged for shares in one or more of the units that are spun off.

On October 31, 2011, ITT Corporation (a global manufacturer of highly engineered industrial products and high-tech solutions) completed the split-off of its Water business, Xylem and Defense business, Exelis. The two spinoffs were distributed in a "one-for-one" basis and the new ITT underwent a "one-for-two" reverse split. For example, if a person held 10 shares of 
old ITT, after the spinoff those shares were exchanged for 10 shares of Exelis, 10 of Xylem and 5 of new ITT (Sauer, 2011).

An example of a split-up occurred in 2005 when the board of directors of Cendant decided to break up the company. Cendant was a conglomerate built through a series of acquisitions that included real estate companies Century 21 and Coldwell Banker, the car rental business Avis, hotel chains Days Inn, Ramada and Super 8, and travel companies Orbitz, Cheaptickets.com and Galileo International. After a difficult merger with CUC International (a company that ended up being one of the biggest financial frauds in history), Cendant recognized that the conglomerate structure was problematic and decided to split it up into separate businesses (Gaugham, 2011).

Equity carve-outs are defined by Gaughan (2011) as a type of divestiture that involves the partial sale of equity interest in a subsidiary to outsiders. As in the previous cases, a new legal entity is created, but with a stockholder base that may be different for that of the parent selling company, given that part of the new firm stocks are sold to the public. Similarly to spinoffs, the divested company has a different management team and is run as a separate firm. The two main differences with spinoffs are, first, that an equity carve-out comes with a cash inflow from the buyers, and therefore it is not a tax free transaction; and second, as it is a partial sale in which the parent company generally keeps the majority of the shares, the decisions of the new management team are controlled by the parent firm's board.

In 1996, American Airlines performed an equity carve-out for $18 \%$ of its distribution system, Sabre. This new structure allowed Sabre to grow significantly, however, in order to gain more independence and provide services to other airlines, Sabre spun off completely in the year 2000 and started trading as an independent company.

Sell-offs (also known as Buy-outs) are defined by Cusatis et al. (2001) as a divesting method in which the subsidiary is sold outright to another corporation or to the sub's managers in a Leveraged Buy-Out (LBO). A sell-off is similar to an equity carve-out in the sense that it generates a cash inflow to the parent firm, but differs in that the new divested company is independent of the parent firm because no portion of it remains in the parent firm's ownership. 
In 1972 Air France created the hotel chain Le Méridien "to provide a home away from home for its customers." The number of hotels grew fast and by 1991 the chain had 58 properties in Europe, Africa, the French West Indies, Canada, South America, the Middle East and Mauritius. In late 1994, Air France sold off Le Méridien to Forte, a UK hotel giant. The transaction allowed Air France to raise capital and better focus on its core business, the Airline. Le Méridien also gained more focus and became very attractive to hotel companies. As of June 2012, after several mergers and acquisitions, Le Méridien brand and management fee business belongs to Starwood Hotels \& Resorts Worldwide Inc., while the leased and owned real estate assets belong to Starwood Capital, a company that is not affiliated with Starwood Hotels \& Resorts Worldwide Inc. (http://www.starwoodnet.com)

Table 1 summarizes the previously explained similarities and differences of the four types of corporate contraction.

Table 1 - classification of the four types of corporate contraction

\begin{tabular}{|c|c|c|}
\cline { 2 - 3 } \multicolumn{1}{c|}{} & No cash inflow & Cash inflow \\
\hline Depends on parent firm & Tracking stocks & Equity carve-out \\
\hline Independent of parent firm & Spinoff & Sell-off \\
\hline
\end{tabular}

Chemmanur and Liu (2011) developed a theoretical model to analyze company choices among three of these four forms of corporate contraction: tracking stocks, equity crave-out and spinoffs. The analysis is conducted with the objective of maximizing shareholders value. The authors start from the premise that all three forms of restructuring result in an increase of information produced for institutional investors. Based on this premise, they show that firms with the most favorable private information choose to implement spinoffs, those with medium private information choose equity carve-outs, those with less private information choose tracking stocks, and finally, firms with unfavorable private information choose to remain consolidated.

\subsection{Historical trends}

In the 1960 's, the number of divestitures was relatively small compared to the number of mergers and acquisitions. Companies were engaging in major expansions at this time, widely using the acquisition of other firms to increase the acquiring company stock price. With the 
1974 recession, companies felt the need to reconsider some of the previous acquisitions that had proven to be poor combinations. Under the pressure of falling economic demand, companies were forced to sell off divisions to raise funds and improve cash flow. Once the crisis passed, the number of divestitures shrunk and remained low until the 1990's. At that time, the number of divestitures rose again, as downsizing and refocusing became prominent business strategies. This was also the time in which the academic literature started publishing many studies analyzing the matter.

Gaughan (2011) showed how the number of divestitures in the US follows the leading trend of the mergers and acquisitions curve, after a short delay of about two years. Figure 1 shows an intense peak of Mergers and Acquisitions activity in the late 1960s that was then followed by a peak in the divestitures curve in the early 1970's. A similar phenomenon occurred again in the mid-1980s and the early 2000s. But by the mid and late 2000s, two new waves came, in which no delay could be observed. Moreover, divestitures peaked in 2005 before the Mergers and Acquisitions did in 2006.

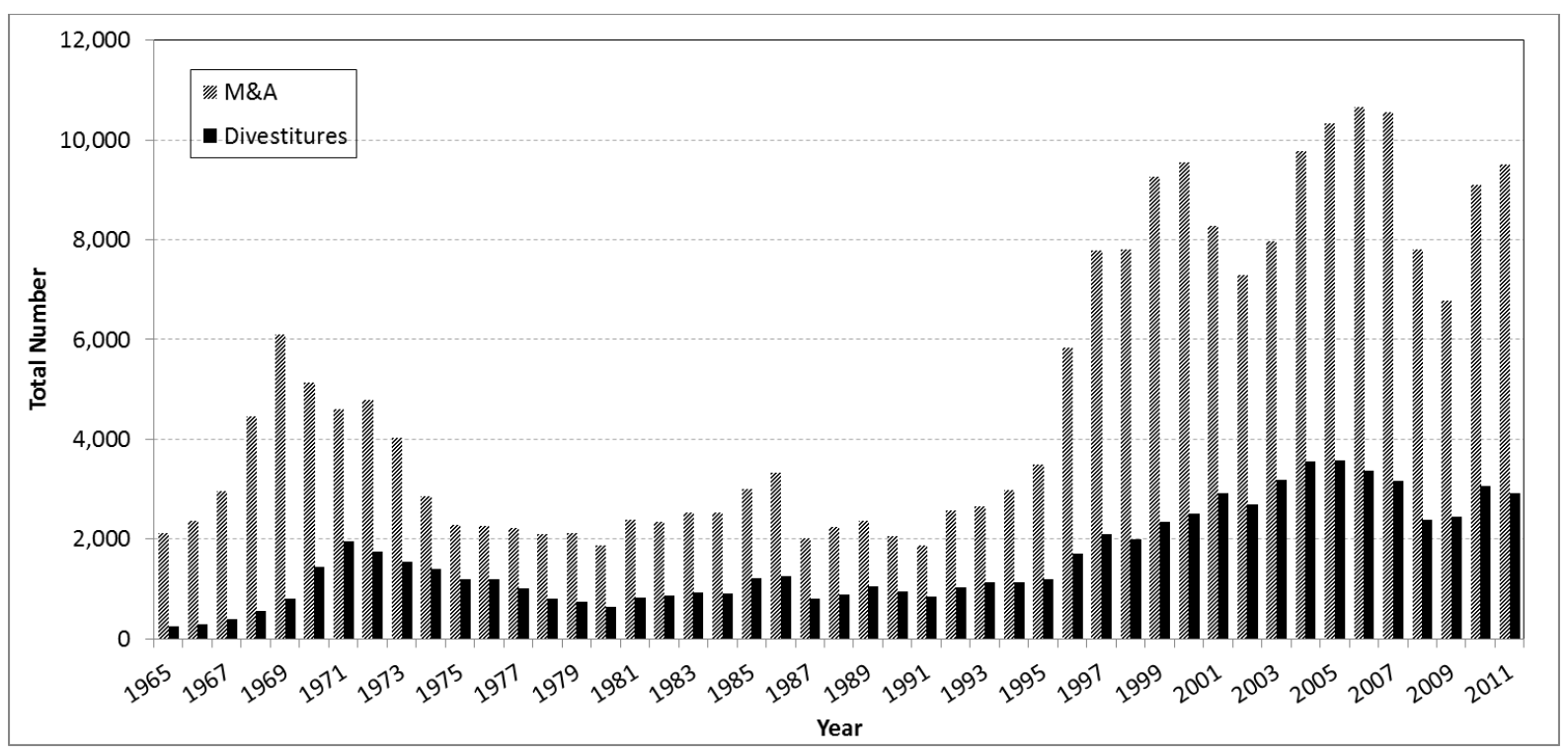

Figure 1 - US Mergers and Acquisitions v/s Divestitures ${ }^{1}$

In the airline industry, the current tendency is for companies to merge. The fierce price war that the many competitors have generated has turned the airlines into a very unprofitable industry. Consequently, in the past decades airlines have started to merge to reduce

\footnotetext{
${ }^{1}$ Source: Mergerstat review, 2012.
} 
competition, expand their networks and take advantage of costs synergy. Table 2 shows some of the recent M\&As of US based and international airlines.

Gaughan proposed that many divestitures are the result of sell-offs of previous acquisitions. Critics of corporate acquisitions use the records of divestitures following poor acquisitions as evidence of ill-conceived expansion planning. However, one can argue that companies sometimes acquire a firm because they are interested only in one particular division. It can be understood that after absorbing the desired division, the company would divest the rest of the acquired firm.

Table 2 - Major mergers and acquisitions of the 21st century

\begin{tabular}{|l|l|}
\hline Year & Mergers or Acquisitions \\
\hline 2000 & Air New Zealand + Ansett Australia \\
\hline 2000 & Air Canada + Canadian Airlines \\
\hline 2001 & American Airlines + TWA \\
\hline 2002 & Japan Airlines (JAL) and Japan Air System (JAS) \\
\hline 2003 & China Southern + China Northern + Xinjiang \\
\hline 2004 & Air France + KLM \\
\hline 2005 & Lufthansa + Swiss Airlines \\
\hline 2005 & America West Airlines + US Airways \\
\hline 2006 & Cathay Pacific + Dragonair \\
\hline 2009 & Republic Airways + Midwest Airlines and Frontier Airlines \\
\hline 2009 & Delta Airlines + Northwest Airlines \\
\hline 2009 & Lufthansa/Swiss + Austrian Airlines \& BMI \\
\hline 2009 & Air France/KLM + 25\% of Alitalia \\
\hline 2010 & Caribbean Airlines + Air Jamaica \\
\hline 2011 & United + Continental \\
\hline 2011 & British Airways + Iberia \\
\hline 2011 & Air India + Indian Airlines \\
\hline 2012 & Southwest + AirTran \\
\hline 2012 & LAN + TAM \\
\hline 2012 & Azul + TRIP \\
\hline
\end{tabular}

To merge successfully, these companies have to match their corporate structure and build parallel accounting systems that can be financially merged. In order to achieve this match and facilitate the merger, sometimes one of the companies has to spin off a division that the other firm does not own or had divested in the past. Examples of such divisions could be a catering provider, a corporate sales agency or a Frequent Flyer Program. 


\subsection{Results}

Several studies in the academic finance literature have documented significant positive results around corporate spinoffs. Some of these studies analyze the stock price reactions at the moment of the spinoff announcement, while others analyze it in the long run. Further studies try to explain those positive reactions in the stock price by focusing on performance improvements measured by indicators such as growth in sales, operating incomes, capital expenditures or return on assets (ROA). These studies found that higher returns occur when the parent firm and its subsidiary operate in different industries, from which they conclude that value creation comes from "corporate focus", meaning that managers focus only on their own business. The following paragraphs describe the mentioned studies in further detail.

In the early 1980s, several researchers documented the positive effects that spinoff announcements have on shareholders' wealth. In their studies they propose three hypotheses that may explain this phenomenon: (1) wealth transfers from bondholders to stockholders, (2) relaxed regulatory or tax constraints, and (3) productivity increases from reducing diversity under one management, allowing both entities to use unique sets of contracts in which each has a comparative advantage. All of the researchers conclude that the third hypopaper is the strongest.

A very interesting study by Hite and Owers (1983) shows positive abnormal returns ${ }^{2}$ to shareholders of 116 firms that engaged in spinoffs during the period of 1963 to 1981 . By examining press announcements detailing the spinoff reasons, the authors classified their sample in four groups: specialization in operations, facilitation of a merger, legal/regulatory difficulties and unknown reasons. The stock price reactions in the two-day interval surrounding the first press announcement showed no substantial differences and were significantly positive for all four categories of spinoffs. But when analyzing the period from the announcement to the initial trading day of the spun off subsidiary, the four groups show substantial differences. Firms that were specializing operations showed returns of $14.5 \%$; firms facilitating mergers showed $11.6 \%$. The firms in the third group chose spinoffs as a response to regulatory or potential anti-trust intervention, and unlike the previous groups,

\footnotetext{
${ }^{2}$ Positive abnormal return is a term used to describe the returns generated by a given security over a period of time that is different from the expected rate of return. The expected rate of return is the estimated return based on an asset pricing model, using a long run historical average or multiple valuation. (Source: investopedia.com)
} 
these firms experienced negative returns of $-4.7 \%$. Finally, the group of firms with unknown spinoff reasons showed a return of $6.6 \%$, which is approximately equivalent to the average of the first three groups. The higher returns of the first two groups are consistent with the reduced diversity efficiency hypopaper.

Veld and Veld-Merkoulova (2004) performed a similar study with 156 spinoffs from companies in 15 different European countries. The authors found an abnormal cumulative average return of $2.62 \%$ over the three-day announcement window, which increase to $2.66 \%$ for the subsequently completed spinoffs. These returns are smaller than the ones found by Hite and Owers, but still in line with US performance.

The positive impact on the stock price does not occur only at the moment of the spinoff announcement or first trading day. These abnormal positive results also arise during the subsequent years in which operational improvement actually takes place. Cusatis et al. (1993) measured the stock returns of spinoffs, their parent firms, and spinoff-parent combinations for periods of up to three years following the spinoffs. In order to create a comparable base, they analyzed the spinoff and parent firm performance using raw and matched-firm-adjusted returns. The authors found significantly positive abnormal returns for spinoffs, their parents, and the spinoff-parent combination. Table 3 provides the mean returns for the spinoffs and the parent companies for sub-periods corresponding to 6,12, 24 and 36 months after the initial day of trading. These increasing returns suggest that spinoffs provide superior long term returns to investors of both the parent and the subsidiary.

\section{Table 3 - Mean returns of common stock for spinoffs and parent firms ${ }^{3}$}

\begin{tabular}{|c|c|c|c|c|}
\cline { 2 - 5 } \multicolumn{1}{c|}{} & \multicolumn{4}{c|}{ Percent returns for each holding period } \\
\cline { 2 - 5 } \multicolumn{1}{c|}{} & 6 months & Year & 2 years & 3 years \\
\hline Spinoff & 7.7 & 19.9 & 52.0 & 76.0 \\
\hline Parent & 11.3 & 23.1 & 54.0 & 67.2 \\
\hline
\end{tabular}

The authors also found that many of the firms in the study experienced a subsequent takeover. Both spinoffs and their parent firms experience significantly more takeovers than do control groups of similar firms and the abnormal returns in their stock price are limited to those firms involved in takeover activity. Because of this finding, the authors conclude that spinoffs

\footnotetext{
${ }^{3}$ Source: Cusatis et al. (1993).
} 
provide a low-cost method of transferring control of corporate assets to acquiring firms who will create greater value.

To explain the increases in the parent and spinoff stock prices, Daley, Mehrotra, and Sivakumar (1997) examined the relationship between spinoffs and corporate focus by comparing the performance of spinoff firms when the parent company and the spun off entity were in two different Standard Industry Classifications (SIC) codes (cross-industry spinoffs) relative to instances in which both were in the same SIC code (own industry spinoffs). The study starts from the premise that dispositions involving assets outside of the core business of a firm are viewed by the market as increasing in value while dispositions of core assets are not. The shedding of these non-core assets is referred to as "increasing corporate focus." Analyzing the 85 spinoffs in the study, the authors looked for evidence to prove the premise, while also distinguishing what the source of this value creation was.

The results, looking at the three-day announcement period, showed significantly abnormal returns around the time of the announcement of cross-industry spinoffs only, which supports the initial hypopaper. The authors found substantial improvements in ROA and various other measures of performance for cross-industry spinoffs but not for own industry deals. They interpreted this difference as indicating that performance improvements provide an explanation for the value increase surrounding spinoff announcements, and that this is associated with increasing corporate focus. The authors conclude that cross-industry spinoffs create value only when they result in an increase in corporate focus. They attribute the performance improvements to companies removing unrelated businesses, allowing managers to avoid distraction of noncore entities and focus attention on the core operations they are best suited to manage.

To complement the findings of Daley et al. (1997), Desai and Jain (1999) examined the corporate focus and increased returns relationship in the long-run stock market performance. They claim that the full impact of the managerial action is likely to be captured only through a long-run study. Their results for the three day announcement period are similar to Daley et al. findings. However, they show that the superior performance of the focus-increasing spinoffs persists in the post-spinoff period. Table 4 shows the returns for the focus-increasing spinoffs and the non-focus-increasing spinoffs over periods of three days post announcement, as well 
as one, two and three years following the spinoffs. The results are similar when the parent firm and the subsidiary are examined separately.

Table 4 - Returns of focus and non-focus increasing spinoffs after different time periods ${ }^{4}$

\begin{tabular}{|l|c|c|c|c|}
\cline { 2 - 5 } \multicolumn{1}{c|}{} & \multicolumn{4}{c|}{ Percent returns for each holding period } \\
\cline { 2 - 5 } \multicolumn{1}{c|}{} & 3 days & 1 year & 2 years & 3 years \\
\hline Focus-increasing spinoffs & 4.45 & 11.12 & 20.77 & 33.36 \\
\hline Non- focus-increasing spinoffs & 2.17 & -0.96 & -7.66 & -14.34 \\
\hline
\end{tabular}

Finally, the authors explore potential motivations for undertaking non-focus-increasing spinoffs. They find that the reason to do so is simply because they are spinning off poorly performing subsidiaries. They prove this premise by examining financial leverage and interest coverage ratio to investigate whether these firms are in financial distress. They found no evidence that spinoffs are motivated by a high level of financial leverage or financial distress. Moreover, they do not find any evidence of disproportionate transfer of debt from the parent firms to the subsidiaries through a spinoff.

Veld and Veld-Merkoulova (2009) summarize the findings of previous studies on spinoffs. They conclude that the higher abnormal returns are associated with spinoffs in which there is an improvement of industrial focus. The authors observe that larger spinoffs show higher abnormal returns, which they relate with the industrial focus result, as bigger companies are likely to present higher diversity in their subsidiaries focuses. The authors also find a surprising result that reveals that spinoffs that were not completed show higher returns at the moment of announcement than spinoffs that were completed later. They assume this happens because spinoffs that were ex-post not completed were less expected by the market participants.

\subsection{Sources of value}

We have seen that when a division operates in a different industry than the one of its parent firm, divesting it allows managers on each separate entity to focus only on their own industry which results in better performance for both parent and subsidiary. Separating parent firm and subsidiary helps to "unlock hidden value" by correcting the undervaluation of certain parts of

\footnotetext{
${ }^{4}$ Source: Desai and Jain (1999).
} 
a conglomerate firm. This section presents different explanations for the positive abnormal returns that are observed in all different types of corporate contraction.

Anslinger, Klepper and Subramaniam (1999) analyze spinoffs, equity carve-outs and tracking stocks. The authors propose that gains in stock prices flow from four changes. First, there is an increase in coverage by analysts. By exposing the division to the market, its operating performance becomes more transparent, which raises shareholder returns by revealing hidden value. The authors explain that this transparency does not come from a greater quantity of information provided by the company, which could happen without restructuring ownership, but from an improvement in the quality of coverage by analysts. They can dedicate better quality time to the separate companies because now each is categorized more specifically in their own industry. In other words, the increase in return comes from accepting that the conglomerate was being undervalued, also known in the academic literature as "diversification discount", and that through a spinoff this lower valuation can be corrected.

Second, the restructured subsidiaries attract new investors. Empirical evidence demonstrates that there is a small overlap between people who invested in a parent company and those who invest in its subsidiaries after a restructuring. To sustain this observation, the authors took 55 examples of all types of divestiture and compared the top 25 shareholders of the parent and the subsidiary. On average, ownership overlapped by only $17 \%$ to $27 \%$. A fair explanation for this small overlap in investors is that, in theory, the market values a company as the sum of its parts, analyzing the growth prospects of each of the separate businesses and using the market view of predicted cash flows to determine the price of the stock. But in practice, the market consists of many investors with their own individual criteria for making a purchase. The problem is that investors who find a particular division of a company attractive might reject the stock of the parent firm because, for example, it competes in a less attractive line of business or has slower growth prospects.

Third, as shown in Section 1.3, restructuring of ownership generally improves the operating performance of both parent and subsidiary. Through issuing new equity, a company can offer managers incentives tied to the market performance of the divisions they run. This way, managers can clearly indicate to investors, executives, and other employees, that performance, ownership, risk and reward are bound together. In contrast, if the two entities operate together, conflicts of interest can lead to a sub-optimal performance of one division, for the 
benefit of a different area in the company. This occurrence is also known as reverse synergy, which means that the parts are worth more separately than they are within the parent company's corporate structure.

Finally, restructuring can improve corporate governance and increase strategic flexibility, which can be achieved by pushing management accountability deeper into the organization. For a subsidiary that is newly exposed to the market, greater examination by investors and analysts creates a level of pressure to which management must respond. Operating performance generally improves as a result. For management in poorly performing businesses, the new accountability becomes tangible through lower compensation when the stock weakens. Additionally, spinoffs can increase the strategic flexibility of businesses by allowing a subsidiary to form relationships with companies that do not want competitive information to flow to its parent firm. After being spun off from AT\&T, Lucent was better able to do business with international telecommunications companies that perceived its parent firm as a rival.

For the case of sell-offs, the source of value generation lies in the fact that the high bidders of the divested subsidiary are likely to get more benefit from it, while the parent firm will probably get more benefit from the cash than from the subsidiary profits. When the market responds positively to this asset reallocation, it is expressing a belief that the firm will use the cash more efficiently than it was utilizing the asset that was sold. The selling firm has several options when it is contemplating the disposition of the newly acquired cash. It may pay the cash to stockholders in the form of a dividend or it may repurchase its own shares at a premium. Either option will give the stockholders an immediate payout. Alternatively, the firm could retain the cash and use it to pay debt or to finance internal investment.

Chemmanur and Yan (2003) present a new explanation for the performance and value improvements that follow spinoffs. They develop a theoretical model to demonstrate that spinoffs increase the probability of a takeover by a better management that will improve value. The model consists of a firm with two divisions under one current management and a rival management team that wants to get control of one of the divisions. Giving up control can benefit shareholders, but involves a loss of control by the current management. A spinoff increases the chances of losing that control, motivating the current management to two possible choices: either work harder on running the firm or relinquish control of one of the 
two divisions to the rival management. Both choices lead to an increase in the combined equity value. The authors also show that spinoffs can increase value even when there is no better rival management to take over the division, just by serving to discipline firm management.

\subsection{Concerns}

Despite all the mentioned advantages of a corporate contraction, companies sometimes hesitate because they fear the costs and complexity that a restructuration may bring. The following paragraphs describe some of the main concerns that firms face when they analyze a divestiture.

Loss of stability: When performing a spinoff, the parent firm may doubt the ability of the subsidiary to survive independently. In the case of tracking stocks and carve-outs, some companies may fear that the subsidiary might be taken over by their rivals, or that analysts could exert pressure to spin it off completely. However, according to Anslinger et al. (1999), a look at the survival rate of divestitures shows that of the 23 US-listed tracking stocks issued between 1984 and 1999, only two were sold (Ralston Purina's Continental Baking Group and USX's Delhi Group) and two were spun off (the Media Group from US West and EDS from GM). The remaining 19 were still trading as tracking stocks. For carve-outs and spinoffs the story was much the same. Fully, $77 \%$ of the majority-owned equity carve-outs created between 1988 and 1993 were still trading as independent companies five years after issue. Similarly, $76 \%$ of the 129 spinoffs survived at least five years. Of those that are no longer trading, $81 \%$ were taken over and $19 \%$ delisted after filing for bankruptcy.

Redundancy and complexity of separate operations: When issuing new equity greater complexity is expected to arise. On the one hand, the board of directors will have to be responsive to more than one set of shareholders. Moreover, the creation of equities to attract different types of investors places a burden on senior management to communicate effectively and consistently with each group. On the other hand, companies have some internal divisions that provide service for the operations of both parent and subsidiary. Examples of such divisions are the website, call centers, sales offices and the R\&D department. Afterwards, the parent firm and subsidiary will have to provide these services separately, losing the previous synergy. Additionally, in the cases in which parent and subsidiary maintain business 
relationships after the spinoff, the subsidiary will have to maintain interaction with many of the parent's departments. In a scenario of separate equity, the complexity of these interactions is expected to increase.

Transaction costs: According to Anslinger et al. (1999), the direct transaction costs associated with raising new capital in the market through an equity carve-out can represent $2 \%$ to $5 \%$ of the transaction's total value; for a spinoff or tracking stock, the figure is around $2 \%$. The higher percentage for carve-outs may reflect the fact that their offerings often come in the form of an IPO and not a stock distribution. On top of these transaction costs, divestitures that will maintain a business relationship must account for the costs of developing a robust agreement. Furthermore, a subsidiary might want to pursue business with its parent's competitors. The Sabre Group, for instance, provides reservation systems not only for American Airlines, its parent, but also for American's rivals.

This Section has defined the different types of divestitures, followed by historical trends, performance and the main factors involved. Although there are a large number of papers covering this field of study, there is little research on the contractual relationships that the parent and spun off company need to develop when these two entities pretend to maintain tight commercial interactions. The following section presents real examples that will contribute in finding the important factors that the parent firm and the spun-off subsidiary need to take into consideration before they close the deal.

\section{Case studies}

After having defined and understood spinoffs and divestitures in general, this Section analyses three cases of spinoffs around the airline industry. Airlines are a very difficult industry in terms of profits. Since deregulation in 1978, many airlines have born and died. The industry has faced alternate periods of gain and loss that have been amplified through time. In the last decade the picture has become even more complex, which can be seen in Figure 2.

The three cases presented below are focus-increasing spinoffs, in which the parent firm and the subsidiary have a different Standard Industry Classification (SIC) codes. Because of this cross-industry situation, the academic literature suggests that the three cases are expected to 
present positive results. Unfortunately, not all the presented cases show a positive outcome. Through the analysis of these three cases, a new finding is presented. When a parent firm and its divested subsidiary are going to maintain a business relationship after splitting up, what determines the success of the divestiture is the robustness of the agreements that the entities sign, prior spinoff. Among the three cases presented below, the first one requires no future relationship and the outcomes predicted by the academic literature indeed occur. The second and third cases consider a very important business relationship after the spinoff. In one of them, the previous agreements were very robust, while in the other, many flaws can be found. The results, as expected, are very different.

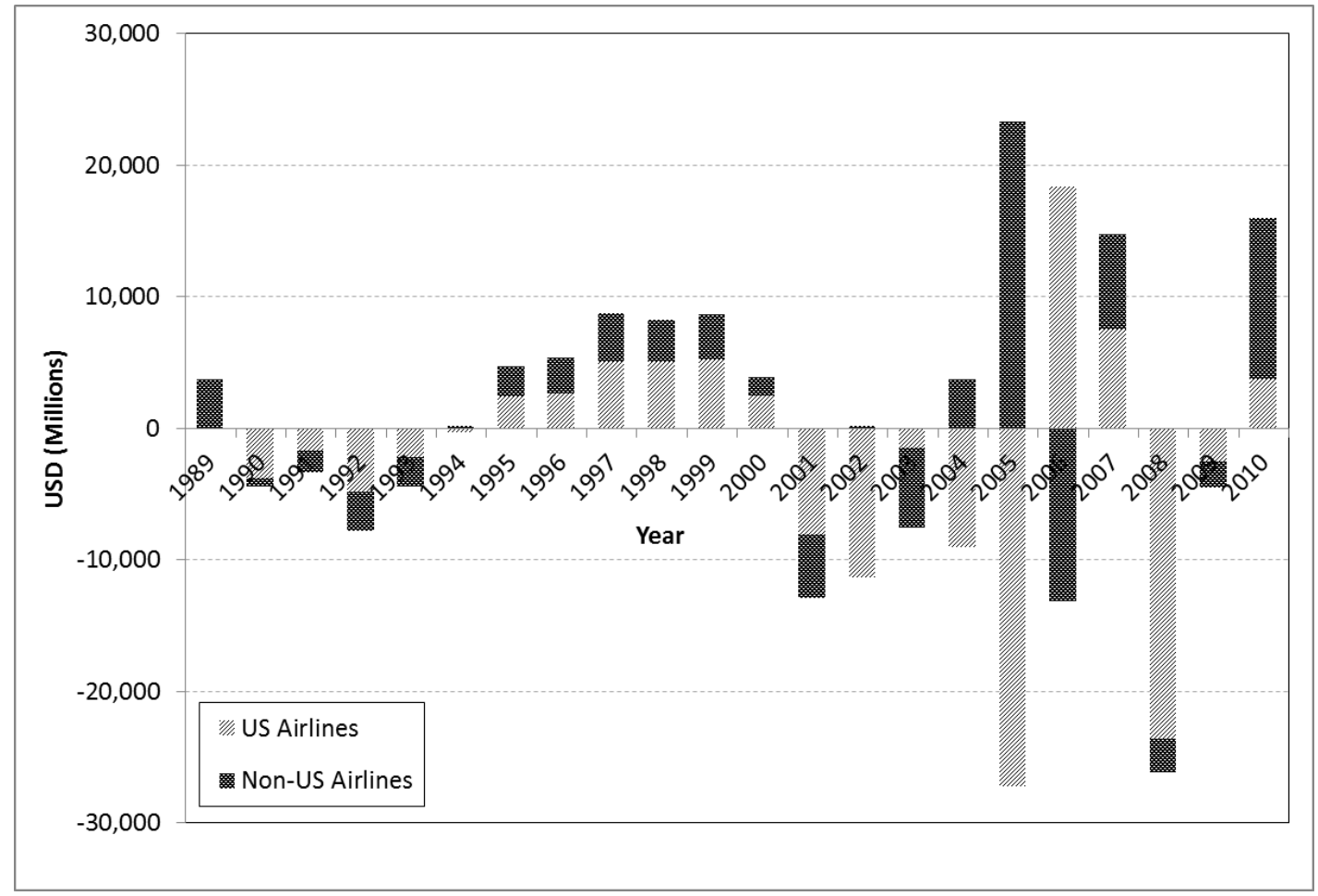

Figure 2 - World Airline Net Profit 1989-2010 (Source: IATA)

\subsection{Expedia spins off TripAdvisor}

The spinoff of TripAdvisor from its parent Expedia is a very clean example that illustrates many of the concepts presented in Section 1. Stephen Kaufer, CEO and co-founder of the subsidiary, explained in a public interview that "the evolution of TripAdvisor into an independent, public company is about unlocking shareholder value." 
Expedia is one of the largest online travel agency in the world. The company allows business and leisure travelers to book flights, cruisers, hotels, cars and many other travel related services. At the same time, Expedia allows travel suppliers to post their inventory and fares in a much known website that customers visit very frequently. On the one hand, the website benefits a travel supplier by driving in more demand. But on the other hand, the supplier is hurt because it must drop prices for customers to choose it over other competitors. This sort of price war is the biggest benefit for the consumers and the reason why they visit Expedia in the first place. Consequently, the website provides a vast opportunity for advertising, as it reaches a very valuable audience.

TripAdvisor is also a travel website, but unlike Expedia, it does not sell anything to travelers. TripAdvisor assists customers for free in gathering travel information, posting reviews and opinions of travel-related content and engaging in interactive travel forums. TripAdvisor is one of the earliest adopter of user-generated content. Users are the ones that provide most of the website content, and they also do it for free. In order to generate profit, TripAdvisor is supported by an advertising business model, boosted by the popularity that the website has earned.

Expedia has the classic search tool in which the client enters origin, destination and dates, to find flights, hotels, cars and more. TripAdvisor on the other hand, asks the user to enter the name of a hotel and/or city and then the web site shows reviews, pictures, promotions and similar options. TripAdvisor also offers links to different web based agencies for flights and hotels, such as Orbitz, Travelocity, Priceline and Expedia, among others, so that customers can check prices and availabilities.

\subsubsection{History and Business Plan}

This section relates a brief history of Expedia and TripAdvisor along with their business strategies, as it is presented in the two companies' websites.

Expedia was created in 1996 as a small division within Microsoft. The division was an online travel booking site, which gave consumers the option of research and travel booking from their laptops, with no help of a travel agent. Three years later, when Expedia was no longer about software technology, the company spun out of Microsoft, and became a publicly traded 
company on NASDAQ under the symbol EXPE. The site runs through multiple Global Distribution Systems (GDSs) including Amadeus and Sabre for flights and Worldspan and Pegasystems for hotels.

In 2002, InterActiveCorp's (IAC), an e-commerce company that was taking over multiple internet firms, acquired a controlling interest in Expedia. This new parent firm allowed Expedia a faster growth thanks to the synergies with IAC's other travel holdings. In the subsequent years, IAC acquired more travel related companies including the websites Hotels.com, and Hotwire; corporate travel management company Egencia; and the traveler reviews \& opinions site TripAdvisor. TripAdvisor was founded in 2000 by Stephen Kaufer, and financed by Flagship Ventures, the Bollard Group and a few private investors.

In 2005, Chairman Barry Diller spun off all its travel businesses, including TripAdvisror, under the name Expedia, Inc. The intention was to diminish the confusion investors had about the ungainly IAC and that way unlock shareholders value. Expedia became an independent business again, fully dedicated to online traveling, aiming to "become the largest seller of travel in the world" ${ }^{, 5}$ by helping everyone everywhere plan and purchase everything in travel.

In April 2011, Expedia announced its intentions to split into two publicly traded companies by spinning off the TripAdvisor brand of travel sites. Although TripAdvisor is part of the online traveling market, it differs from the other Expedia brands in the sense that it is not selling anything to travelers. TripAdvisor finances itself through advertising of other brands. In an interview to the news agency Reuters, Expedia CEO Dara Khosrowshahi explained that the separation "allows the two businesses to be pure plays and to operate with the proper amount of focus to grow respectively.” In late 2011 Expedia, Inc. spun out TripAdvisor Media Group but retained its successful travel transaction brands. TripAdvisor started trading on the NASDAQ under the symbol 'TRIP' and IAC chairman Barry Diller became TripAdvisor's chairman.

TripAdvisor is the giant in the travel reviews space. Every minute the site publishes 25 new contributions and features over eight million candid traveler photos. The reviews site operates

\footnotetext{
${ }^{5}$ Expedia's Mission
} 
in 30 different countries in Europe, Asia Pacific, the Americas and the Middle East. Besides the company's main revenue stream of cost-per-click advertising, TripAdvisor also includes TripAdvisor for Business, a dedicated division that provides the tourism industry access to TripAdvisor's millions of monthly visitors.

\subsubsection{Financial Results}

The spinoff of TripAdvisor from Expedia has shown results that are in line with the predictions of the academic literature. Figure 3 shows how the value of the Expedia stock jumped in April 2011 at the time of the spinoff announcement increasing its value by $13 \%$ in only a day. In the following three months the stock value increased an additional $21 \%$. These two positive returns reflect the investors' belief in the effectiveness of a spinoff.

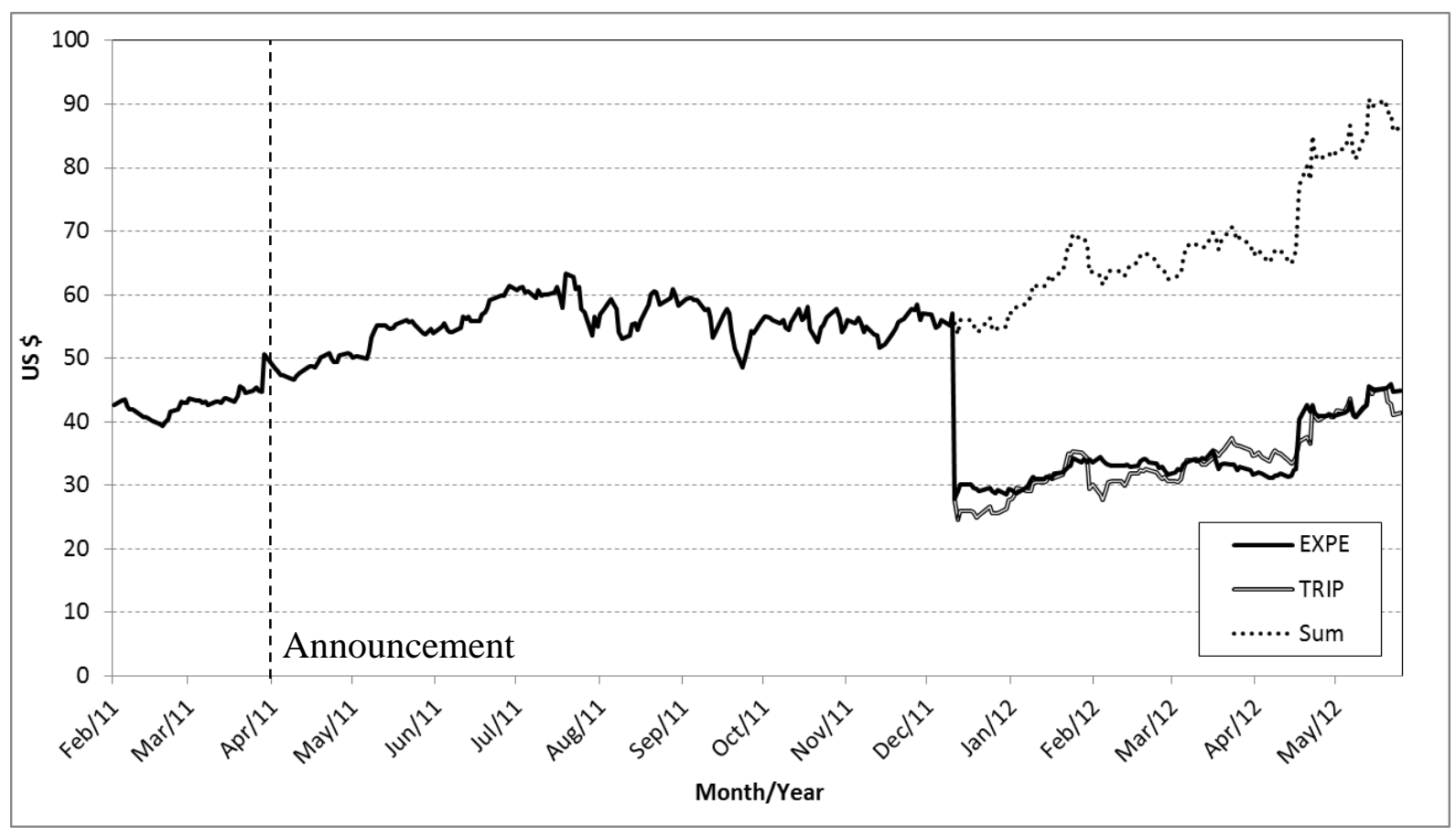

Figure 3 - Stock price of Expedia, TripAdvisor and the sum after spinoff ${ }^{6}$

From August 2011 the stock price remained relatively flat around \$55, until December 2011, where the spinoff formally took place. At that point the value of the Expedia stock dropped by almost half, but if the initial value of the new TripAdvisor stock is added, then the total shareholders value remained almost the same. Yet, in the six months post spinoff, both parent

\footnotetext{
${ }^{6}$ Source: Bloomberg.
} 
and subsidiary stocks grew again by approximately 55\%, revealing that investors recognized that the separate managements of both companies are now focusing better in their respective industries. The day before the spinoff, the Expedia stock was worth $\$ 44.8$; fourteen months later the new Expedia stock is worth that same value and the TripAdvisor is worth an additional \$41.5. Assuming no other effects (which can be supported by the fact that the stock of Expedia's direct competitor, Orbitz, dropped $1 \%$ in that same period), this result can be interpreted as if the Expedia Inc. of April 2011 was undervalued by almost half.

\subsection{Air Canada spins off its FFP, Aeroplan}

Air Canada, founded in 1936, is Canada's largest full-service airline. It serves over 170 destinations in five continents and is a founding member of Star Alliance, one of the world's most extensive air transportation networks.

A Frequent Flyer Program (FFP) is a type of loyalty program that rewards passengers for their ticket purchases with miles or points to gain their fidelity. Clients enrolled in the program can exchange their points for more flight tickets, use them to obtain an upgrade from coach to business class, or exchange them for goods or services of other companies registered in the program. The first airline in the world that came up with the idea of a fidelity program was Texas International Airline in 1971. Their idea was to give special fares to frequent customers, but they never managed to implement it. In 1981 American Airlines launched AAdvantage, the first FFP with the format we know today. It was quickly followed that same year by United Airlines with MileagePlus and Delta Airlines with SkyMiles. (Rowell, 2010). Nowadays, most airlines offer a FFP to their clients.

Airlines also benefit by having a FFP. First, clients stay loyal because in order to keep earning points they are more inclined to choose this airline over its competition. And second, the enrollment of the clients facilitates the airline's data analysis when it comes to customer behavior.

An FFP spinoff meets the condition of corporate focus. An airline's main activity is to provide transportation for passengers and freight, in other words, move them from point $\mathrm{A}$ to point B as fast, safely and profitably as possible. The FFP's activity, on the other hand, is to 
capture clients' loyalty while making good use of distressed inventory ${ }^{7}$. The Airline's source of profit comes from the margin of selling air tickets, freight space and other ancillary revenues. The FFP on the other hand has a different set of three sources of profit. The first one is the difference between the sales price of miles and the cost of the goods and services that are given as awards. A second source of profit comes from the percentage of miles that are never used. Aeroplan estimates this portion as $17 \%$. Finally, the third source comes from the fact that redemption of miles occurs, on average, 30 months after accrual. The FFP invests its sales money during these 30 months before spending it on rewards, and receives interest.

Because of the different nature of Air Canada's and Aeroplan's value generation, it makes sense to have these two entities work independently and focus on their own purposes.

This second case relates the spinoff of Aeroplan, Air Canada's FFP, as described by Aeroplan itself in its Annual Information Form (AIF), an annex of the company's annual report. An examination of Aeropan's business model follows, accompanied by the financial performance that the two entities have shown since the spinoff.

\subsubsection{History}

Air Canada was founded in April 1936 as Trans-Canada Airlines (TCA) by legislation of the Canadian federal government. The airline was a subsidiary of the Canadian National Railway. By 1964, TCA had become Canada's largest national airline, and in 1965 its name changed to Air Canada. In the late 1970s, Air Canada became an independent corporation, ending the government's direct regulatory control over Air Canada's routings, fares, and services. Deregulation of the Canadian airline market, under the National Transportation Act of 1987, officially opened the airline market in Canada to equal competition.

In July 1984, Air Canada launched Aeroplan, a FFP fully integrated with Air Canada's operations. In the following decade, the program grew rapidly in members and added several travel-related partners. In 1991, Aeroplan obtained its first non-travel related partner: a bank named CIBC, with which they launched the Aerogold Visa card. During this period, Aeroplan also implemented three classifications: Elite, Prestige and Super Elite, designed to recognize and reward its most frequent travelers with additional benefits.

\footnotetext{
${ }^{7}$ Distressed inventory is the inventory whose potential to be sold at a normal cost has passed or will soon pass.
} 
On January 2002, Aeroplan was established as a wholly-owned limited partnership of Air Canada with a dedicated management team focused on the development of the Aeroplan Program. With this new format, the membership base began to grow even more rapidly and more partners were added. Aeroplan also renegotiated its long-term agreement with CIBC, resulting in an increase in revenues per each mile sold. This renegotiation also allowed for less restrictive exclusivity provisions, which resulted in a long-term agreement in 2004 with American Express, a multinational financial service corporation that, through its well-known credit cards, holds a very popular Membership Reward program. In addition, Aeroplan made a strategic shift to expand the reward portfolio by offering non-flight and specialty rewards. Today, Aeroplan's roster of non-flight rewards includes more than 800 specialty, merchandise, gift card and experiential rewards, as well as hotel and car rental rewards.

On April 1, 2003, Air Canada went bankrupt and filed for protection under the Companies' Creditors Arrangements Act, the equivalent of the US's Section 11. Eighteen months later, the company emerged from bankruptcy as a subsidiary of ACE Aviation Holdings Inc., a company created with the propose of bringing Air Canada back to regular business.

In June 2005, ACE, the new parent of Air Canada, performed an equity carve-out selling $12.5 \%$ of the division Aeroplan for $\$ 250$ million through an IPO. Although the idea of divesting the FFP was already in the mind of some US airlines, ACE made Air Canada the first airline in the world to actually acomplish it. Aeroplan Income Fund became the first publicly traded loyalty program in the world. The growth of the company continued and two major events occurred during the three subsequent years of partial ownership.

The first event was Aeroplan's acquisition of Loyalty Management Group (LMG), a loyalty marketing business, based in Wales, England. LMG owned and operated the leading coalition loyalty program in the United Kingdom: the Nectar Program. A few years later, and under Aeroplan's command, the program launched Nectar Italy in collaboration with Groupe Auchan, a French international retail group, and Nectar Chile in collaboration with Cencosud, the largest retail company in Chile and the third largest retail company in Latin America.

A second major event that took place during this partial ownership period was a very significant improvement on the flight reward portion of the FFP. This improvement was intended to increase the program's value proposition to its members. To do so, Aeroplan 
maintained its previous reward grid called ClassicFlight and added ClassicPlus, both of which are explained below. Through ClassicFlight, every month Air Canada offers the FFP $8 \%$ of its seat capacity on every route, at a low flat mileage rate defined for each route based on its length. With ClassicPlus the FFP can offer its members unrestricted access to available seat inventory in both economy and executive class, by charging mileage levels that vary depending on what paid fare is being offered for the flight. Aeroplan uses an innovative availability and booking tool to source seat inventory and to calculate redemption mileage levels on a real-time basis. The number of Aeroplan miles required to redeem a flight ticket is based on actual airline ticket prices minus Aeroplan's negotiated discounts, as the airline's largest purchaser of seats. Thus, the number of miles required varies in a way similar to airline pricing, depending on factors such as origin, destination and seasonality, as well as the time and day of travel.

In late 2006, ACE performed an equity carve-out of Air Canada, its main business, and the Airline was listed again in the Toronto stock exchange. As of June 2012, ACE still holds part of Air Canada's ownership, but it is planning to distribute its assets back to its shareholders by mid-2013. From 2006 to 2008, ACE sold all of its remaining holdings of Aeroplan, through special distributions to its shareholders or sale on the secondary market. By May 2008 the FFP was no longer under direct control of neither ACE nor Air Canada. Aeroplan Income Fund, initially created as an income trust, converted to a public corporation in June 2008 and subsequently changed its name to Groupe Aeroplan Inc.

On October 5, 2011, Groupe Aeroplan Inc. changed its name to Aimia, a global loyalty management company with millions of members that earn Aeroplan miles and are part of a growing network of over 75 world class partners, representing more than 150 brands in the financial, retail and travel industries.

\subsubsection{Business Model}

Aimia is a global leader in loyalty management, whose principal business activities fall into three categories: i) coalition loyalty programs, ii) loyalty marketing services and iii) other related services, such as data analytics. This paper focuses in the coalition loyalty programs category, because that is the one that runs the FFP Aeroplan. 
As a coalition loyalty owner and operator, Aimia is responsible for establishing relationships with Commercial Partners, issuing the applicable points or miles. Aimia also has responsibility for the programs in terms of funding any required reserve, owning the redemption liability and managing and earning breakage. In general terms, the coalition loyalty business is based on two major streams of activity: First, the sale of points and related marketing services to accumulation partners; and second, the delivery of rewards to members through the purchase of rewards or shopping discounts from its redemption partners.

Aimia derives most of its revenues from the sale of points and marketing services to its accumulation partners. The marketing services consist primarily of advertising and promotion related services. Members accumulate points through their purchases of products and services from an extensive network of accumulation partners, representing brands in credit and charge cards, grocery, airline, retail and other industries. Once members have accumulated a sufficient number of points, they are entitled to redeem those points for shopping discounts or from reward portfolios offered through Aimia's various Redemption Partners.

Upon the redemption of points, Aimia purchases airline seats, shopping discounts or other products or services in order to deliver the reward chosen by the member. At such a time, Aimia incurs and recognizes an expense equal to the cost of the reward, and the deferred revenue related to the points being redeemed is recognized as earned revenue. The other significant expenses incurred by Groupe Aeroplan in relation to the operation of coalition loyalty programs include contact center expenses, information technology costs and selling and administrative expenses.

Based upon past experience, management anticipates that a number of points issued will never be redeemed by members. This is known as Breakage. By its nature, Breakage is subject to estimates and judgment, and is recognized as revenue prorated over the estimated average life of a point. For the Aeroplan Program that average life is 30 months and it represents the average period elapsed between the sale of a mile and its redemption for rewards. For the Nectar Program the estimated life of a point is 15 months.

On an ongoing basis, the total estimated future redemption cost for outstanding points is determined by Aimia as the product of first, the total outstanding number of unredeemed points on a specific measurement date net of estimated Breakage, and second, the average unit 
cost per points redeemed in the period. Given that the future unit cost per point redeemed may fluctuate, the Future Redemption Costs liability is periodically revalued using the actual average unit cost per point redeemed, incurred in the most recent period. Finally, this future redemption cost is paired with a present cash asset that Aimia can invest during the 30 month period before purchasing rewards.

\subsubsection{Agreements}

As two independent companies, Air Canada and Group Aeroplan engaged on a long-term strategic relationship that includes several agreements. One of these agreements states that Aeroplan is required to purchase annually a minimum number of reward travel seats on Air Canada Flights, representing $85 \%$ of the average number of seats utilized in the three preceding calendar years. Based on the three years ending on December 31, 2010, Aeroplan is required to purchase reward travel seats amounting to approximately $\$ 417.8$ million each year. In a like manner, Air Canada is required to purchase, on an annual basis, a preestablished number of Aeroplan miles at a specified rate. The annual commitment is based on $85 \%$ of the average total Aeroplan Miles actually issued in respect of Air Canada flights or affiliate products and services in the three preceding calendar years. The estimated minimum requirement for 2011 is $\$ 215.3$ million. Through these two agreements and many others that are part of the long-term strategic relationship, the two entities protect themselves from abrupt changes in the structure of the other entity.

The long-term strategic relationship also includes agreements to prevent competition. Air Canada is not permitted to create or participate in any other FFP or customer loyalty recognition program and Aeroplan cannot provide services to any other transportation business that competes with Air Canada. However, these agreements exclude some Star Alliance member airlines and their respective FFPs. In 2009, Aeroplan added TAM Airlines and two new Star Alliance partners, Brussels Airlines and Continental Airlines, to its roster of travel partners. In 2010, Aeroplan further announced the addition of Aegean Airlines to the Star Alliance group, bringing the total number of airline partners to 33. As all of these partners primarily operate in different markets, competition with Air Canada is prevented. 


\subsubsection{Stakeholders Analysis}

The following analysis shows the interactions among the main stakeholders in the loyalty generating system. These main stakeholders are the FFP, the airline, the partners (all represented as one standard partner), and the clients (all represented as one standard client). Figure 4 shows these four stakeholders and their interactions.

In Figure 4, arrows with the same pattern represent interactions that happen at the same time. The award transaction among client, FFP and airline is shown by the arrows in the left of Figure 4. In this transaction the airline awards a client with miles when he makes a ticket purchase, in order to get his loyalty. Depending on the flight length and the ticket type (full or discounted fare) the client receives a different number of miles. The airline has to purchase these miles from the FFP at a previously agreed price. That price must satisfy two conditions: First, the price cannot be higher than the loyalty valorization that the airline perceives; otherwise, the airline has no incentive to purchase the miles. Second, the price must be high enough to cover for the FFP expenses in reward tickets; otherwise the FFP has no incentives to be in the business as their balance would always be negative. Using these two boundaries the two entities will have to agree on a price that prevents them from transferring value from one to the other.

A second award transaction, now among the client, the FFP and a partner, is represented by the right side arrows in Figure 4. Here the partner is the one that wants to award miles to one of its clients for a purchase that this client makes to the partner. The price that the FFP charges the partner for these miles must also satisfy the two conditions described previously. However, the price charged to the partner does not need to be the same price charged to the airline. Given that the airline has more leverage in the equation, it will be charged less. Moreover, the price charged to different partners does not need to be the same either. Depending on the negotiations in every contract, each partner could be charged differently.

The reward transaction is represented by the top and center arrows. This transaction consists of rewarding a client with a flight ticket in exchange for some of his miles. The client decides he wants to redeem his miles, so he chooses a flight. The airline then calculates the cost of that flight ticket, which is not necessarily the same as the ticket price. The airline then communicates this cost to the FFP as a transfer price. Based on the FFP strategy and that 
transfer price, the FFP calculates a price in miles to be charged to the client. If the client agrees with the miles price, all the reward transactions occur. If the client does not like the price or his miles are insufficient, then the transactions do not occur, but the information of the inquiry is saved in a database for future studies. All of these cost calculations must be automatized so that the client receives an instant response on his inquiry.

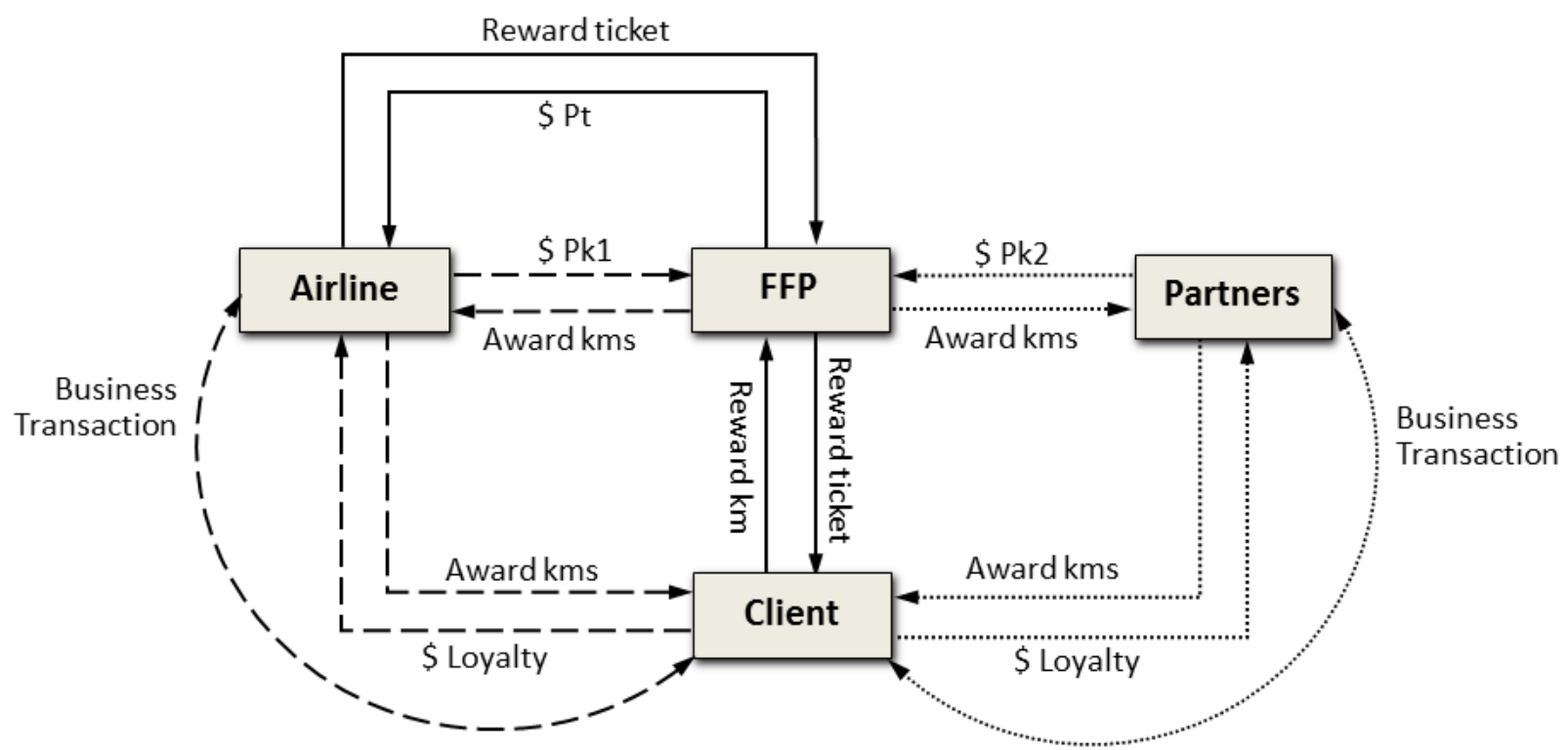

Figure 4 - Stakeholders interactions Architecture diagram

Finally, there could be a final transaction, not represented in Figure 4, to show a reward from a partner to a client through the FFP. The client gives miles away in exchange for a product or service provided by the partner, not the airline.

\subsubsection{Financial Results}

To analyze shareholders value before and after these companies separated, this section first recapitulates the ownership events that have occurred in the past decade:

- By the year 2000, Air Canada was an independent firm listed in the Toronto stock exchange under the name AC.

- In 2003, Air Canada goes bankrupt and emerges in October 2004 as ACE Aviation Holdings, traded in the Toronto stock exchange under the name ACE. 
- In May 2005, ACE announced its intentions of offering an IPO for part of Aeroplan.

- In September 2005, ACE sold part of Air Canada's FFP Aeroplan through an equity carve-out. Aeroplan started trading in the Toronto stock exchange.

- From September 2005 to February 2006, ACE kept 85.6\% of ownership of Aeroplan. After that ACE ownership was reduced to $75.3 \%$ until the end of 2006. By the end of 2008, ACE had sold all of its ownership on Aeroplan.

- In December 2006, ACE performed an equity carve-out of Air Canada and the airline was listed in the Toronto stock exchange again under its old name AC (in series A and B)

- In Octber 2011, Aeroplan changed its name to Aimia began trading in the Toronto stock exchange under the name AIM.

Figure 5 shows the total market value of Air Canada and Aimia and compares them with the SP500 index for Airlines. Because AirCanada did not trade in the stock exchange from October 2004 to December 2006, the figure shows an adjusted market value of ACE instead. ACE's market value has been adjusted by subtracting the value of its ownership in Aeroplan, to better represent Air Canada alone.

After the equity carve-out announcement in May 2005, ACE's shares increased their value by $7 \%$ in the first day and $12 \%$ in the first week and a total of $24 \%$ in the first month, with which ACE reached its highest market value in its history. During the subsequent months the stock price dropped back, and by the day of the IPO its value was the same as three month earlier when the divestiture had been announced.

Right after the IPO, the market value of Aeroplan stayed relatively steady around $\$ 2,500$ million of Canadian dollars for about nine months. However, in the subsequent months, Aeroplan's value starts increasing, reaching a peak of almost twice its initial amount in October of 2007, after two years of separate operations. ACE did not show positive results initially either. Its share price started increasing in October 2006 when they announced the spinoff of Air Canada. 
Once it was divested, Air Canada started behaving very similarly to the world airline industry, which can be observed by comparing its value with the SP500 index in Figure 5. In fact, after dropping severely in 2008 , both companies have been following the airline industry trend. This suggests that even though Aeroplan runs a different business, it is highly tied to the airline industry behavior.

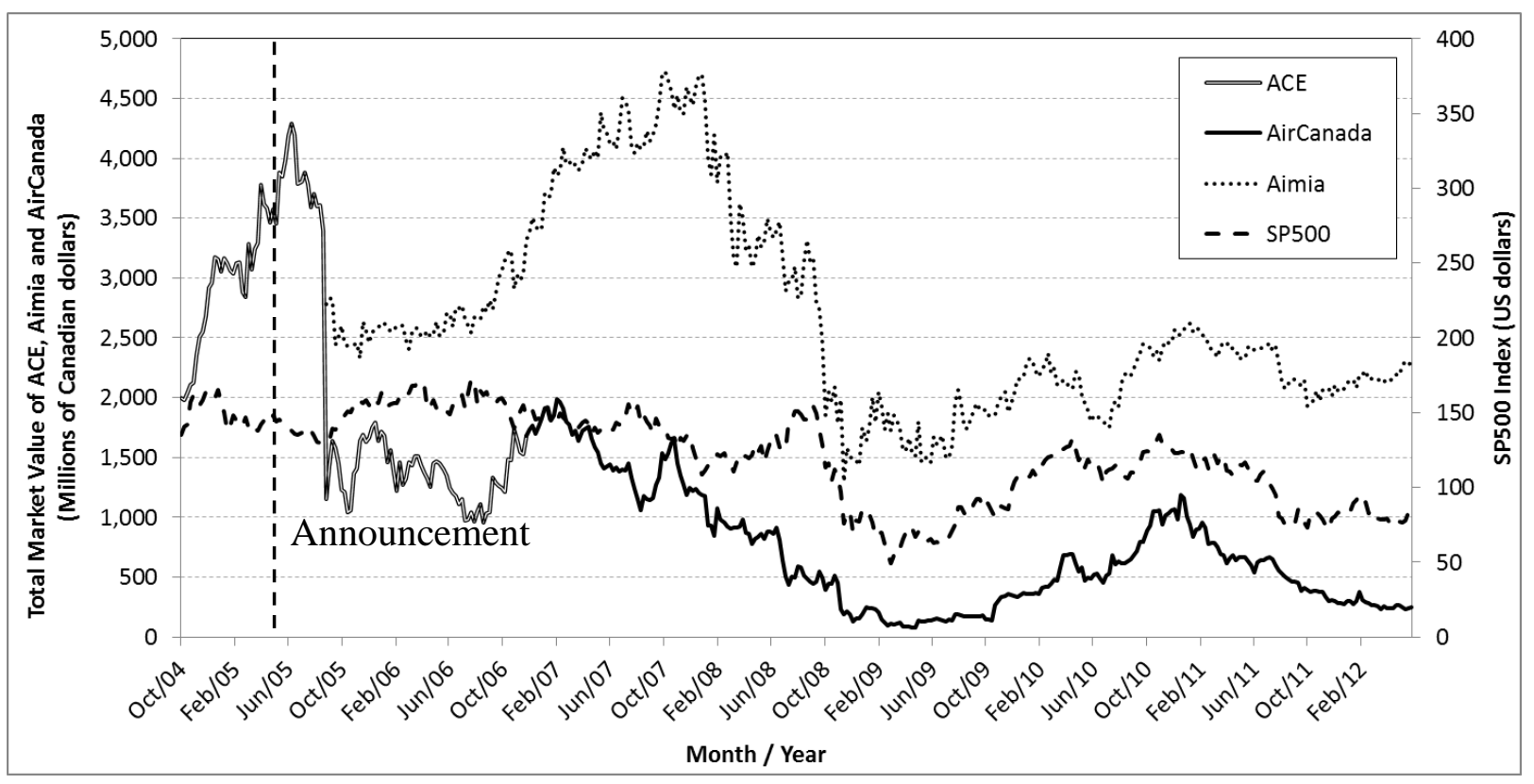

Figure 5 - Stock price of ACE, Air Canada and Aimia v/s S\&P500 index 8

Discounting the effect of the general airline industry's oscillating behavior, Air Canada and Aeroplan have shown positive results. The fact that they are able to work well in an independent structure, despite the dependencies they have to each other, is really remarkable. Air Canada is Aeroplan's main customer; without the airline's partnership the program loses most of its value. At the same time, Air Canada needs to have an FFP in order to maintain competitiveness in the market. Almost every airline offers a rewards program nowadays; not offering one could cost the airline many of its customers. The companies have very important leverages on each other and yet they manage to work well. My belief is that these good results lie in the fact that this two companies took the time to write very strong and fair agreements before they split up in two separate companies. This idea will be discussed again after presenting a final case, in which the relationship post-spinoff has not been as smooth as the one between Air Canada and Aeroplan.

\footnotetext{
${ }^{8}$ Source: Bloomberg.
} 


\subsection{American Airlines spins off its distribution system, Sabre}

American Airlines Inc. (AA), the principal subsidiary of AMR Corporation (AMR), was founded in 1934, but traces its roots back to the early days of aviation in the 1920s. In early 2012, American Airlines, American Eagle and the AmericanConnection carrier served 260 airports in more than 50 countries and territories with, on average, more than 3,300 daily flights. The combined network fleet numbered nearly 900 aircrafts. AA is a founding member of the Oneworld alliance and is headquartered in Fort Worth, Texas, adjacent to the Dallas/Fort Worth International Airport.

Sabre is a Global Distribution System (GDS) that functions as a shop window in which airlines, including AA, and other travel service providers can publish their service inventory. Agencies all over the world can access Sabre and sell these services separately or in a combined mode. In 2004, Sabre worked with approximately 350,000 travel professionals and connected them with more than 400 airlines, 13 cruise lines, 50 rail providers 93,000 hotels and 25 car rental brands (Sabre Annual Report, 2004).

Sabre was created by AA in the 1950s. The division became an equity crave-out in 1996, spun off completely from AA in 2000 and became private in 2007. After the spinoff, the relationship between AA and Sabre has not been as smooth as the one between Air Canada and Aeroplan. This section relates the history and business plan as presented by AA and Sabre on their websites, followed by some recent events collected from the news that reflect some of the problems that the separate entities have faced.

\subsubsection{History}

In the 1950s, a high growth in AA's passenger demand made it very hard for the airline to handle flight reservations. Flight bookings were managed through a manual system, run by eight operators who would sort cards for every flight in a rotating file. To book a seat an operator would place a mark on the side of a card and visualize whether the flight was full. The system had limited room to scale, as eight operators maximum could fit around the file. To solve the problem, in 1952, AA introduced the "Magnetronic Reservisor", an electromechanic computer that replaced the card files. This new system allowed for a large number of operators to look up information simultaneously and tell ticket agents over the phone 
whether a seat was available. However, a staff member was still needed at each end of the phone line, so handling tickets still took a considerable amount of effort.

In 1953, the president of AA, Cyrus Rowlett Smith, was traveling on an AA flight to New York when he met R. Blair Smith, a senior sales representative for IBM. They started talking about an idea for a data processing system that could create and manage airline seat reservations and instantly make that data available electronically to any agent at any location. Six years later, the ideas became a reality: AA and IBM jointly announced their plans to develop a Semi-Automated Business Research Environment, better known as SABRE, the first real-time business application for airline seat bookings.

Between 1960 and 1962, AA installed the first Sabre system on two IBM 7090 computers, located in a specially designed computer center in Briarcliff Manor, NY. The state-of-the-art mainframe system processed 84,000 telephone calls per day. The initial research, development and installation investment in this system took 400 man-years of effort at a development cost of almost US\$40 million. In 1964 the network was completed, becoming the largest private, real-time data processing system, second only to the U.S. government's system. The system became an integral part of AA, saving the airline $30 \%$ of its investments in distribution staff.

In 1972, Sabre moved to a new consolidated computer center in Tulsa, Oklahoma, that was designed to house all of AA's data processing facilities. In 1976, the system was installed in a travel agency for the first time, triggering the wave of travel automation. By the end of the year, 130 locations had received the system. Technology was improving very fast, boosted in part by the feedback of its main users: the travel agencies. Thanks to these improvements, by 1978, the Sabre system could store over one million fares.

During the 1980's, the technology of the system continued to improve. In 1984, a low-fare search capability called "Bargain Finder SM" was introduced. This tool, completely new in the industry, could automatically advise which class of service was the least expensive for the flights booked. In 1985, a new tool called "easySabre" was introduced. This tool allowed consumers using personal computers to tap into the Sabre system via online services, and access airline, hotel and car rental reservations. In 1986, Sabre released the industry's first revenue management system, helping maximize airline income by optimizing the fare at 
which each seat was sold. Along with its revenue management system, Sabre invented the virtual and continuous nesting concepts, which improved the efficiency of the system and are still used today. Because of its rapid growth and genius inventions, Sabre became a division of AMR, the parent company of AA, in 1986.

In 1992, Sabre introduced the "AirFlite" flight scheduling system, enabling the development of flight schedules that meet the airline's customer preferences. With such many technological improvements, Sabre's system was able expand its market by extending coverage to the United Kingdom and providing software, consulting and systems management services to other airlines in areas such as revenue accounting, yield management and crew scheduling.

In 1996 AMR performed an equity carve-out of the Sabre Group through an IPO of $18 \%$ of its equity. That same year, Sabre launched "Travelocity.com", the first online travel agency that allowed consumers themselves not only to access Sabre's fare and schedule information, but also to reserve, book, and purchase tickets without the help of a travel agent or broker. In 1998, Sabre formed a joint venture with ABACUS International to establish the "SabreSonic" passenger solution as the GDS market leader in Asia. In 1999, Sabre introduced "Best Fare Finder pricing", which allowed travel agents to search for flights based on fare rather than schedule.

On March 15, 2000, Sabre and AA separated completely when Sabre spun off from AMR. In the following decade, Sabre kept expanding to Europe and Asia Pacific mostly through acquisitions, and launched the "Aerodynamic Traveler", a passenger processing tool designed to expedite the airline check-in process and reduce long lines at airports through the use of curbside check-in, roving agents and self-serve kiosks. Unfortunately, technological improvements on the reservation tool slowed down significantly.

By 2007, Sabre Holdings had become a very profitable company, with a high penetration in the travel industry. Sabre's growth had reached approximately 9,000 employees in 45 countries. Because of its success, the company was acquired in March by two private-equity firms, Silver Lake and TPG, in a transaction valued at approximately $\$ 5$ billion, including the assumption of $\$ 550$ million in debt. Through this transaction, Sabre became a privately owned company and stopped trading in the stock market. 


\subsubsection{A new industry was born}

After AA launched Sabre in the 1960s, other airlines decided to copy the idea and established their own systems for their personal use. In 1968 Delta Air Lines launched the Delta Automated Travel Account System (DATAS). Trans World Airlines and United Airlines followed in 1971 with the Programmed Airline Reservation System (PARS) and the Apollo Reservation System, respectively. In 1976, United was the first that began offering its Apollo system to travel agents; while it would not allow the agents to book tickets on United's competitors, the marketing value of the convenient terminal proved indispensable. Sabre, PARS, and DATAS were soon released to travel agents as well. Following airline deregulation in 1978, an efficient distribution system became a particularly important tool to have. In fact, Texas Air executive, Frank Lorenzo, purchased money-losing Eastern Air Lines specifically to gain control of its SystemOne distribution system.

In Europe, British Airways, British Caledonian and CCL joined Videcom International in 1976 to launch Travicom, the world's first multi-access reservations system. Travicom provided distribution for these two airlines to thousands of travel agents in the UK. Soon more airlines decided to join Travicom (including TWA, Pan American World Airways, Qantas, Singapore Airlines, Air France, Lufthansa, SAS, Air Canada, KLM, Alitalia, Cathay Pacific and JAL). By 1987, Travicom handled 97\% of UK airline bookings. Videcom decided to replicate the globalization of the system in other areas of the World including the Middle East, New Zealand, Kuwait, Ireland, Caribbean, United States and Hong Kong. British Airways, who by then owned $100 \%$ of Travicom, chose to participate in Videcom's development and form, in 1993, the Galileo International system.

Other European airlines that had been investing during the 1980's in distribution systems, decided to join efforts. In 1987, a consortium led by Air France and West Germany's Lufthansa developed Amadeus, modeled on SystemOne. Amadeus Global Travel Distribution was launched in 1992, allowing its airline members to better handle the increasing demand, offer better services and share power. In 1990, DATAS II (a division of Delta Air Lines) and PARS partnerships companies (owned by TWA and Northwest Airlines, Inc.) decided to follow the globalization trend and formed Worldspan, with headquarters in Atlanta, Georgia. 
To the date, Sabre, Galileo, Amadeus and Worldspan are the dominant giants of the GDS industry. Galileo and Worldspan are both owned by Travelport ${ }^{9}$, but they operate as separate platforms. Numerous smaller companies have also formed distribution systems in niche markets not served by the four largest networks. These companies include the Low Cost Carrier segment and some small and medium size domestic and regional airlines.

\subsubsection{Business Model}

Sabre is organized in four business units:

- Sabre Travel Network is Sabre's GDS, the biggest and most important division of the company. Sabre Travel Network is one of the world's largest GDS along with Galileo, Amadeus and Worldspan.

- Sabre Airline Solutions provides technology solutions for airlines by offering the industry's largest Software-as-a-Service (SaaS). Their software includes a reservations system and a commercial planning and operations tool used by more than 300 airlines and over 100 airports around the world.

- Sabre Hospitality Solutions provides a reservations system, marketing and distribution software, and Internet marketing and e-business solutions for the hospitality industry. These solutions are used by more than 12,000 hotel properties around the world, generating more than US\$12 billion in revenue each year for its customers.

- Travelocity, an online travel company, provides consumer-direct travel services for leisure and business travelers. It markets and distributes travel-related products and services directly to individuals through Travelocity and its various brand websites and contact centers, and websites owned by its supplier and distribution partners.

A traditional airline manages the distribution of its inventory in three main stages. I like to call them the Factory, where the inventory is created, the Warehouse, where the inventory is stored, and the Shop window, where the inventory is displayed for clients to see and purchase. Figure 6 presents a diagram with the detail of these three stages.

\footnotetext{
${ }^{9}$ Travelport was born in 2006 as one of the spinoffs that resulted from the Cendant conglomerate split-up. In its beginnings, Travelport owned Galileo and Orbitz (a web agency), and in 2007 the company acquired Worldspan.
} 


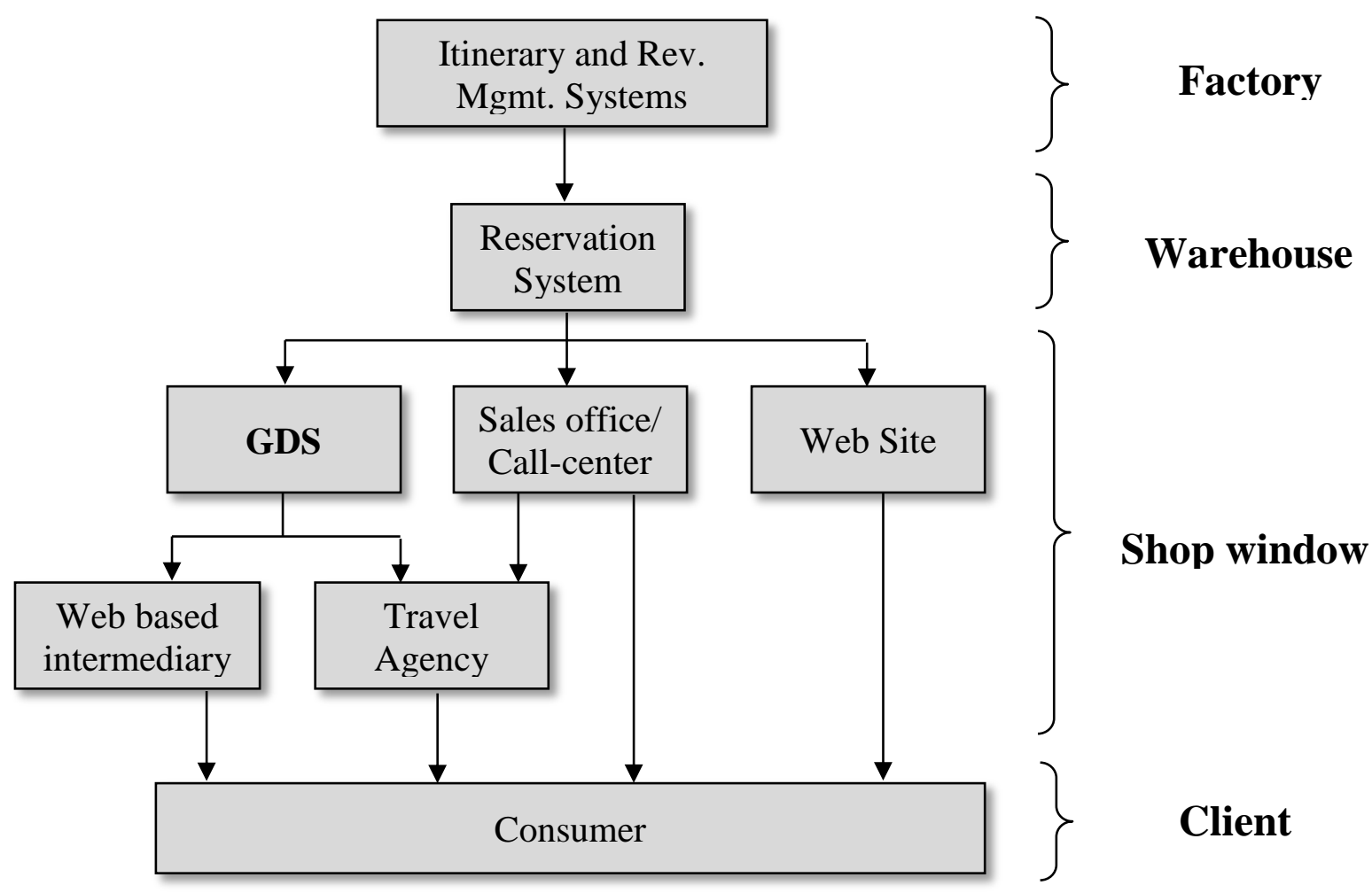

Figure 6 - Systems Architecture Diagram

The Sabre Airline Solutions business unit is a tool that can help airlines manage their Warehouse and/or Factory. In the Factory, airlines first decide where to fly, daily frequencies, schedules and size of aircraft. With all of these inputs they create an itinerary. Then, airlines use a Revenue Management system to define different fares with specific regulations for each destination and to decide when to make each fare available in order to maximize revenues. Sabre Airline Solutions, as well as other vendors, sells software to optimize the itinerary and the fares.

In the Warehouse, the airline stores the optimized result of the previous stage and accounts for the seats that have been already sold or seats that get canceled. For these purposes, the warehouse must be in constant communication with both the factory and the shop window. Sabre Airline Solutions also sells software to accomplish this task.

In the Shop window, all seats and their fares stored in the warehouse are presented to the customers. These customers can access them through different channels. The direct channels are through the airline website, call center or ticketing offices. The problem with these channels is that customers go to them only if they know about the airline and remember about 
it when they are looking to purchase a ticket. The indirect channels are travel agencies and web based intermediaries, also call web agencies. Examples of web agencies are Expedia, Travelocity and Orbitz. These agencies and web agencies access the inventory of many different airlines in parallel through one or several GDSs, one of which is Sabre Travel Network.

Customers generally prefer to search for flight tickets through indirect channels because thanks to the GDS that runs in the back, they can see many airlines at the same time and compare them in terms of price, schedule and service. Clients can also find alternatives that come from connecting two flights from different airlines, which is something that those airlines may have not been able to offer through their direct channels.

Because of this preference of clients for indirect channels over direct channels, GDSs have won a tremendous amount of power over airlines. GDSs charge an airline an average of $\$ 1.3$ per booking, an amount that tends to increase every time that there is a renegotiation. And just like cellphone carriers, the four biggest GDSs try to tie in their customers to not lose them to a competitor. For example, in 2002, Sabre announced its Direct Connect Availability three-year Option (DCA-3), a new multi-year offering for airlines in a participating carrier agreement. In exchange for an established booking fee rate, the carrier commits to the highest level of participation in the GDS.

\subsubsection{Agreements}

When American Airlines and Sabre separated, they were not as careful as Air Canada and Aeroplan in building their agreements. Although the beginning of the relationship was smooth, after a decade their disputes have gone so bad that and AA ended up suing Sabre.

In their initial agreement, AA was committed to pay a fixed fee for each AA booking made through Sabre. Because of the high flight ticket fares charged in the early 1990's, this fixed fee represented a very small percentage of the price of an average ticket. However, later on, when competition increased and fares started dropping, the distribution fee became a more significant percentage of the price. The airline had to reduce all of its costs in order to be able to charge less, but the distribution cost could not be reduced. 
A second problem was that after the initial agreement expired, Sabre started to increase the fixed fee, not based on anything else than their negotiation power. Sabre was one among only four of the controlling GDS, while AA was one of the hundreds of Sabre's customers.

\subsubsection{Financial Results}

Figure 7 presents the total market value of Sabre and AMR, AA's parent firm, along with the Standard \& Poor 500 index for the airline industry. The chart shows that while Sabre was still mainly owned by the airline until the year 2000, AA's market value behaved very similar to the SP500 index. After the spinoff in 2000, the previous market value split approximately in two, and the market value of each separate company kept behaving similarly to the SP500 index, but with Sabre performing proportionally better than AA from 2002 to 2006. In 2007, Sabre was bought by private investors and AA's market value jumped, mainly because most other major US airlines were facing bankruptcy. AA made an enormous effort at that time by restructuring internally in order to avoid bankruptcy. Unfortunately, the internal efforts were not enough; during 2011 revenues did not cover the costs and AA went bankrupt by the end of 2011 (Bloomberg).

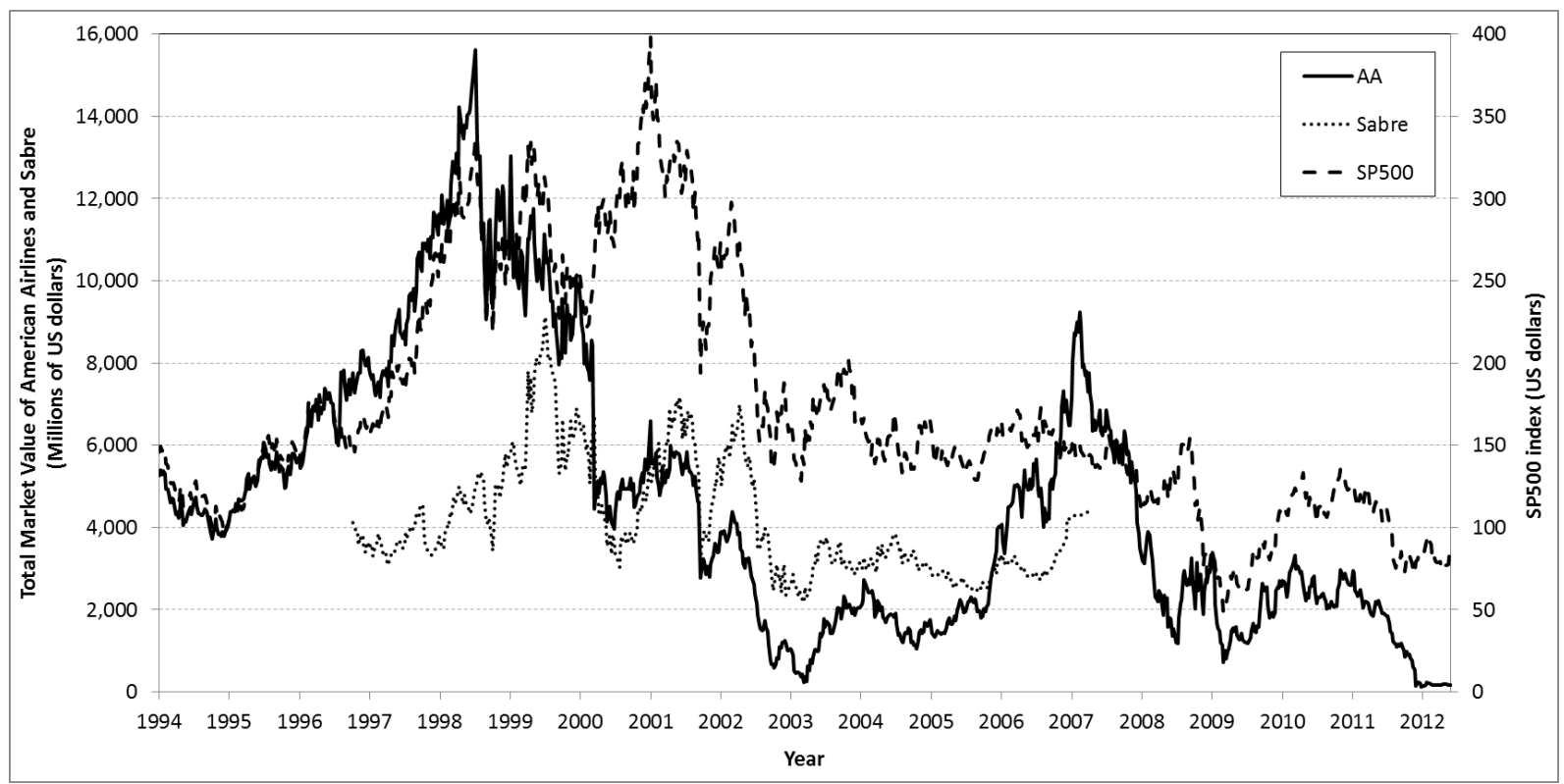

Figure 7 - Stock price of American Airlines and Sabre v/s S\&P500 index ${ }^{10}$

One of AA's biggest costs comes from the fees it has to pay to Sabre and other GDS for the bookings that are sold through them. In the latest years, the GDSs have been increasing its

${ }^{10}$ Source: Bloomberg. 
fees. AA tried to fight this increasing cost during 2011; some of the actions that the airline took during that year are related next.

\subsubsection{Recent events}

On January 5th 2011, American Airlines filed a complaint against Sabre, for biasing AA availability and shopping displays in the Sabre GDS. The airline qualified this action as “wrongful and unjustified retaliation that threatens to seriously disrupt American's business and harm members of the public and the travel industry." They said that this bias was making it very difficult for travel agents to find and book AA's flights in Sabre, and that it is a violation of the American-Sabre full-content agreement. Sabre is AA's largest non-direct booking source; in 2010, $\$ 7$ billion of its sales were booked through Sabre. The GDS was looking to more than double the booking fees it charges to American, a move that would increase the airline's distribution costs by $\$ 157$ million annually. When the airline declined, Sabre decided to bias AA's availability. Five days later, AA obtained a temporary restraining order barring Sabre from biasing its flights in Sabre and AA flights and fares were back in the Sabre system in the manner they appeared before Sabre took the action January 5 th. $^{11}$

A few months later, AA filed another lawsuit against Sabre, Travelport and Orbitz Worldwide alleging that the three GDS companies were engaging in anticompetitive behavior to exclude AA from entering and competing in the GDS market. Later in the year, AA and Sabre agreed to extend their current content agreement until after American's antitrust claim against Sabre settled. The agreement gave travel agencies and corporate customers continued access to AA's content via Sabre until 14 days after the antitrust claim against Sabre in Texas state court had been resolved (which has not happened as of June 2012). A similar extended agreement was signed with Travelport, meaning that AA was also continuing to appear on the Worldspan and Galileo GDSs. ${ }^{12}$

In April 2011, US Airways also took action by filing an antitrust action against Sabre. The airline alleged that the GDS had engaged in anticompetitive behavior in order to secure monopoly power in the GDS market. US Airways was concerned because $35 \%$ of its revenue

\footnotetext{
${ }^{11} \mathrm{http}: / /$ www.tnooz.com/2011/02/01/news/american-airlines-sues-travelport-and-placates-travel-agencies-onsurcharge/

${ }^{12} \mathrm{http} / / /$ www.travelweekly.co.uk/Articles/2011/08/31/38053/american+and+sabre+extend+gds+deal+pending+c ourt+case.html
} 
came from tickets booked through Sabre and its affiliated travel agents, giving the GDS "disproportionate" market control, according to US Airways. The airline claimed that Sabre was forcing travel agents to rely on a single GDS to purchase tickets by the imposition of penalties to agents using a different system. US Airways' complaint alleges that Sabre has "engaged in a pattern of exclusionary conduct to shut out competition, protect its monopoly pricing power and maintain its technologically-obsolete business model." Sabre filed a motion to dismiss these accusations in July 2011, arguing that US Airways was merely attempting to renegotiate its contract with the GDS and that the monopolization complaint was based on an incorrect market definition ${ }^{13}$ As of June 2012, the United States Justice Department (DOJ) has initiated an investigation of possible anticompetitive behavior by the GDS companies. No resolutions have come to light yet.

\section{Conclusion}

The airline industry presents cases of both successful and unsuccessful spinoff. This paper has presented three different cases. Expedia and TripAdvisor, show a recent spinoff that has done well so far, mainly because the two separate entities don't need to maintain a complicate business relationship. Air Canada and Aeroplan have also been successful, although they need each other greatly, because they negotiated a very robust agreement before performing the spinoff. Finally, the relationship between American Airline and Sabre has been a real challenge, as they established poor agreements prior the spinoff, that did not took into consideration how important and powerful GDS's were going to become.

This paper has reviewed the existing academic literature on value creation through corporate contraction. The four different forms of corporate contraction are tracking stocks, spinoffs, equity crave-out and sell-offs. In all of these forms, new stocks are issued for the divested subsidiary. The four versions differ from each other in the extent of independence that the subsidiary gains after the separation and whether the transaction brings or not a cash inflow for the parent firm.

\footnotetext{
${ }^{13} \mathrm{http}: / / \mathrm{www}$. tnooz.com/2011/01/10/news/american-airlines-sues-sabre-over-display-bias-and-booking-feeincrease/
} 
Studies show that, in general, the four forms of deconglomeration have positive returns for shareholders, especially if the parent firm and the subsidiary operate in different industries. Investors seem to have a preference for firms that operate in one single industry rather than conglomerate firms. Their lower valuation for conglomerate firms is known as "diversification discount". Gaughan (2011) explains that performing a spinoff is partly fueled by investors' pressure to release internal values that are unrealized in the company's stock price. Splitting the companies increases shareholders value by attracting new investors, increasing coverage by analysts, improving operating performance and increasing strategic flexibility.

To complement these findings, this paper focuses on what happens after the spinoff of crossindustry companies, when parent firm and subsidiary have to maintain business relationships. When the companies follow different courses and do not need each other much, like Expedia and TripAdvisor, then a cross industry spinoff is very likely to be successful. But, if the companies need each other in the future, like Air Canada and Aeroplan or AA and Sabre, then success will depend on the level of robustness of the previous agreements. Before performing a spinoff, both parent firm and subsidiary must define the agreements that will rule their future relationship. These agreements must consider as many potential future scenarios as possible, in order to both protect and give flexibility to the parent firm and the subsidiary.

Air Canada and Aeroplan made a very strong agreement in which the price of the goods that they sell to each other (flight tickets and miles or points) is calculated automatically based on general performance indicators. The availability of seats that the airline offers the FFP is also part of the agreement and is defined based on a proportion of seats in each route and each month. Additionally, each firm is required to purchase a minimum number of goods of the other firm per year, representing $85 \%$ of the average number of goods purchased in the three preceding calendar years. Through these agreements the two entities protect themselves from abrupt changes in the structure of the other entity. Finally, the companies prevent competition by forbidding Air Canada to create or participate in any other FFP and forbidding Aeroplan to provide services to any other transportation business that competes with Air Canada (excluding some Star Alliance member airlines and their respective FFPs).

American Airlines and Sabre did not come up with a very strong agreement in advance. In terms of competitiveness, it is understandable that the airline cannot demand exclusivity 
because the beauty of GDSs is that they are global and show the inventory of many airlines at one time. Consequently, Sabre should not try to force airlines or agencies to publish only through Sabre's GDS and if it does, it should definitely not trammel their ability to switch GDSs over time. When it does, Sabre is being anticompetitive.

In terms of fees, Sabre and AA could have better agreed in a variable fee as a percentage of the ticket price, instead of the fixed fee per booking. Airlines have increased demand by lowering their prices. This action benefits both the airline and the GDS, but only the airline is making the efforts for it to happen. Through the higher volumes of passengers the airline is capable of scaling most of its costs, but not the distribution costs because they remain fixed.

If one takes Sabre's side, it can be seen as unfair that now airlines skip the GDS in their direct sales. Initially, all sales went through the GDS, including the ones made in the airline's office. The reservation system (warehouse) and the GDS (shop window) used to be tied together, but now, airlines have built their own reservation systems in order to skip the GDS in their direct sales. If AA had initially agreed to sell a specific percentage of its bookings through Sabre only, this problem could have been avoided.

Finally, there is an issue around the priority that the GDS uses to display the different options in a flight ticket search. Sabre used to do it alphabetically so that AA would show up first. Now it displays the shorter flights first, and agencies are biased by that. Web agencies have created software to read the entire GDS response and display it in a new order based on price. These software platforms have had to overcome the problems of the obsolete technology that GDSs still use. The lack of technology improvement is in fact another reason of why airlines opted to skip the GDS in their direct web sales.

Strong agreements are a key factor of a spinoff's success when the parent firm and the subsidiary plan to maintain a business relationship. A good practice is to define variable transaction prices that depend on performance indicators of both companies rather than the negotiation power that each may have at a given time. Those variable transaction prices should be evaluated in various scenarios, using modeling tools such as the Montecarlo simulation, to ensure that they will generate a fair outcome. 
Spinoff and other forms of corporate contraction have proven to be an effective way to unlock shareholders value by showing investors separate pictures of the division's performance. This is especially the case when the two divisions operate in different industries. Unfortunately, the initial positive returns can disappear or even become losses if the two divisions plan to maintain business relationships but are not able to come with strong agreements in advance. This paper recommends that airlines and all types of companies dedicate a fair amount of time and effort to build strong agreements prior to the spinoff that are clear, transparent and fair to both parties.

\section{References}

Aimia (2010) Annual Information Form, Financial year ended December 31.

Anslinger, P., Klepper, S., and Subramaniam, S. (1999) Breaking up is good to do, McKinsey Quarterly, vol. 1, pp. 16-27

Belobaba, P. P., Odoni, A., and Barnhart, C. (2009) The Global Airline Industry, Wiley, Chichester, West Sussex, U.K.

Chemmanur, T., and Liu, M. (2011) Institutional trading, information production, and the choice between spin-offs, carve-outs, and tracking stock issues, Journal of Corporate Finance, vol. 17, pp. 62-82.

Chemmanur, T., and Yan, A. (2004) A theory of corporate spin-offs, Journal of Financial Economics, vol. 72, pp. 259-290.

Cusatis, P., Miles, J., and Woolridge, J. (1993) Restructuring through spinoffs: The stock market evidence, Journal of Financial Economics, vol. 33, pp. 293-311.

Daley, L., Mehrotra, V., and Sivakumar, R. (1997) Corporate focus and value creation: evidence from spinoffs, Journal of Financial Economics, vol. 45, pp. 257-281.

Dang, T. Q., Moore, R. (1999) Formal Modeling of Future Demand Forecasting and Frequent Flyer Programs, United Nations University, International Institute for Software Technology, Macau, China.

Desai, H., and Jain, P. (1991) Firm performance and focus: long-run stock market performance following spinoffs, Journal of Financial Economics, vol. 54, pp. 75-101.

Gaughan, P. (2011) Mergers, Acquisitions, and Corporate Restructurings, 5th ed, John Wiley \& Sons, Hoboken NJ.

Hite, G., and Owers, J. (1983) Security price reactions to spinoff announcements, Journal of Financial Economics, vol. 12, pp. 409-436.

Lankford, K. (2000) Trying To Have It All - how tracking stocks work, Kiplinger's Personal Finance Magazine, October 2000

Mergerstat (2012) Mergerstat Review, W. T. Grimm \& Co., pp. 2, 32. 
Rowell, D. (2010). A History of US Airline Deregulation, Part 4: 1979 - 2010: The Effects of Deregulation - Lower Fares, More Travel, Frequent Flyer Programs, The Travel Insider, September.

Sauer, E. (2011) ITT Spin-Off Could Create Buying Opportunity, seekingalpha.com, October.

Tübke, A. (2005) Success Factors of Corporate Spin-offs, Springer, Baltimore, MD.

Veld, C., and Veld-Merkoulova, Y. (2009) Value creation through spin-offs: A review of the empirical evidence, International Journal of Management Reviews, vol. 11, pp. 407-420.

Veld, C., and Veld-Merkoulova, Y. (2004) Do spin-offs really create value? The European case, Journal of Banking and Finance, vol. 28, pp. 1111-1135. 